\title{
The importance of snowmelt spatiotemporal variability for isotope-based hydrograph separation in a high-elevation catchment
}

\author{
Jan Schmieder ${ }^{1}$, Florian Hanzer ${ }^{1}$, Thomas Marke ${ }^{1}$, Jakob Garvelmann ${ }^{2}$, Michael Warscher ${ }^{2}$, Harald Kunstmann ${ }^{2}$, \\ and Ulrich Strasser ${ }^{1}$ \\ ${ }^{1}$ Institute of Geography, University of Innsbruck, 6020 Innsbruck, Austria \\ ${ }^{2}$ Institute of Meteorology and Climate Research - Atmospheric Environmental Research, \\ Karlsruhe Institute of Technology, 82467 Garmisch-Partenkirchen, Germany
}

Correspondence to: Jan Schmieder (jan.schmieder@uibk.ac.at)

Received: 15 March 2016 - Published in Hydrol. Earth Syst. Sci. Discuss.: 11 May 2016

Revised: 15 November 2016 - Accepted: 26 November 2016 - Published: 19 December 2016

\begin{abstract}
Seasonal snow cover is an important temporary water storage in high-elevation regions. Especially in remote areas, the available data are often insufficient to accurately quantify snowmelt contributions to streamflow. The limited knowledge about the spatiotemporal variability of the snowmelt isotopic composition, as well as pronounced spatial variation in snowmelt rates, leads to high uncertainties in applying the isotope-based hydrograph separation method. The stable isotopic signatures of snowmelt water samples collected during two spring 2014 snowmelt events at a north- and a south-facing slope were volume weighted with snowmelt rates derived from a distributed physicsbased snow model in order to transfer the measured plotscale isotopic composition of snowmelt to the catchment scale. The observed $\delta^{18} \mathrm{O}$ values and modeled snowmelt rates showed distinct inter- and intra-event variations, as well as marked differences between north- and south-facing slopes. Accounting for these differences, two-component isotopic hydrograph separation revealed snowmelt contributions to streamflow of $35 \pm 3$ and $75 \pm 14 \%$ for the early and peak melt season, respectively. These values differed from those determined by formerly used weighting methods (e.g., using observed plot-scale melt rates) or considering either the north- or south-facing slope by up to 5 and $15 \%$, respectively.
\end{abstract}

\section{Introduction}

In many headwater catchments, seasonal water availability is strongly dependent on cryospheric processes and understanding these processes becomes even more relevant in a changing climate (APCC, 2014; IPCC, 2013; Weingartner and Aschwanden, 1992). The seasonal snow cover is an important temporary water storage in alpine regions. The timing and amount of water released from this storage is important to know for water resources management, especially in downstream regions where the water is needed (drinking water, snow making, hydropower, irrigation water) or where it represents a potential risk (flood, drought). Environmental tracers are a common tool to investigate the hydrological processes, but scientific studies are still rare for high-elevation regions because of the restricted access and high risk for field measurements in these challenging conditions.

Two-component isotope-based hydrograph separation (IHS) is a technique to separate streamflow into different time source components (event water, pre-event water) (Sklash et al., 1976). The event component depicts water that enters the catchment during an event (e.g., snowmelt) and is characterized by a distinct isotopic signature, whereas preevent water is stored in the catchment prior to the onset of the event (i.e., groundwater and soil water, which form baseflow) and is characterized by a different isotopic signature (Sklash and Farvolden, 1979; Sklash et al., 1976). The technique dates back to the late 1960s (Pinder and Jones, 1969) and was initially used for separating storm hydrographs in humid catchments. The first snowmelt-based studies were 
conducted in the 1970s by Dinçer et al. (1970) and Martinec et al. (1974). These studies showed a large pre-event water fraction $(>50 \%)$ of streamflow that changed the understanding of the processes in catchment hydrology fundamentally (Klaus and McDonnell, 2013; Sklash and Farvolden, 1979) and forced a paradigm shift, especially for humid temperate catchments. However, other snowmelt-based studies in permafrost or high-elevation catchments (Huth et al., 2004; Liu et al., 2004; Williams et al., 2009) revealed a large contribution of event water $(>70 \%)$, depending on the system state (e.g., frost layer thickness and snow depth), catchment characteristics, and runoff generation mechanisms.

Klaus and McDonnell (2013) highlighted the need to quantify and account for the spatial variability of the isotope signal of event water, which is still a vast uncertainty in snowmelt-based IHS. In the literature inconclusive results prevail with respect to the variation of the isotopic signal of snowmelt. Spatial variability of snowmelt isotopic composition was statistically significant in relation to elevation (Beaulieu et al., 2012) in a catchment in British Columbia, Canada, with $500 \mathrm{~m}$ relief. Moore (1989) and Laudon et al. (2007) found no statistical significant variation in their snowmelt $\delta^{18} \mathrm{O}$ data, due to the low gradient and small elevation range (approximately 30 and $290 \mathrm{~m}$ ) in their catchments, which favors an isotopically more homogenous snow cover. The effect of the aspect of the hillslopes on isotopic variability and IHS results in topographically complex terrain has been rarely investigated. Dahlke and Lyon (2013) and Dietermann and Weiler (2013) surveyed the snowpack isotopic composition and showed a notable spatial variability in their data, particularly between north- and south-facing slopes. They conclude that the spatial variability of snowmelt could be high and that the timing of meltwater varies with the morphology of the catchment. Dietermann and Weiler (2013) also concluded that an elevation effect (decrease of snowpack isotopic signature with elevation), if observed, is disturbed by fractionation due to melt/refreeze processes during the ablation period. Aspect and slope are therefore important factors that affect the isotopic evolution of the snow cover and its melt (Cooper, 2006). In contrast, there have been various studies that have investigated the temporal variability of the snowmelt isotopic signal, e.g., with the use of snow lysimeters (Hooper and Shoemaker, 1986; Laudon et al., 2002; Liu et al., 2004; Maulé and Stein, 1990; Moore, 1989; Williams et al., 2009). During the ablation season the isotopic composition of the snowpack changes due to percolating rain and meltwater, and fractionation caused by melting, refreezing and sublimation (Dietermann and Weiler, 2013; Lee et al., 2010; Unnikrishna et al., 2002; Zhou et al., 2008), which leads to a homogenization of the isotopic profile of the snowpack (Árnason et al., 1973; Dinçer et al., 1970; Stichler, 1987) and an increase in heavy isotopes of meltwater throughout the freshet period (Laudon et al., 2007; Taylor et al., 2001, 2002; Unnikrishna et al., 2002). Therefore, the characterization and the use of the evolving isotopic signal of snowmelt water instead of single snow cores is crucial for applying IHS (Taylor et al., 2001, 2002).

There have been various approaches to cope with the temporal variability of the input signal. If one uses more than one $\delta^{18} \mathrm{O}$ snowmelt sample for applying the IHS method, it is important to weight the values with appropriate melt rates, e.g., measured from the outflow of a snow lysimeter. Common weighting methods are the volume-weighted average approach (VWA), as used by Mast et al. (1995), and the current meltwater approach (CMW), applied by Hooper and Shoemaker (1986). Laudon et al. (2002) developed the runoff-corrected event water approach (runCE), which accounts for both, the temporal isotopic evolution and temporary storage of meltwater in the catchment and overcomes the shortcoming of the exclusion of residence times by VWA and CMW. This method was also deployed in several other snowmelt-based IHS (Beaulieu et al., 2012; Carey and Quinton, 2004; Laudon et al., 2004, 2007).

Tracers have successfully been used in modeling studies to provide empirical insights into runoff generation processes and catchment functioning (Birkel and Soulsby, 2015; Birkel et al., 2011; Capell et al., 2012; Uhlenbrook and Leibundgut, 2002), but the combined use of distributed modeling and isotope tracers in snow-dominated environments is rare. Ahluwalia et al. (2013) used an isotope and modeling approach to derive snowmelt contributions to streamflow and determined differences between the two techniques of $2 \%$. Distributed modeling can provide areal melt rates that can be used for weighting the measured isotopic composition of meltwater. Pomeroy et al. (2003) described the differences of insolation between north- and south-facing slopes in complex terrain that lead to spatial varying melt rates of the snowpack throughout the freshet period. The use of the areal snowmelt data from models will likely reduce the uncertainty that arises from the representativeness of measured melt rates at the plot-scale.

The overall goal of our study was to quantify the contribution of snowmelt to streamflow and hence to improve the knowledge of hydroclimatological processes in highelevation catchments. This study aims to enhance the reliability of isotope-based hydrograph separation by considering the distinct spatiotemporal variability of snowmelt and its isotopic signature in a high-elevation study region. This study has the following three objectives: (1) the estimation of the spatiotemporal variability of snowmelt and its isotopic composition, (2) the quantification of the impact of the spatial variability in snowmelt rates and its isotopic composition on IHS, and (3) to assess the combined use of a physically based snowmelt model and traditional IHS to determine snowmelt contributions to streamflow. Distributed melt rates provided by a surface energy balance model were used to weight the measured isotopic composition of snowmelt in order to characterize the event water isotopic composition. Traditional weighting methods (e.g., using plot-scale observed melt rates) were compared with the model approach. 
(a)

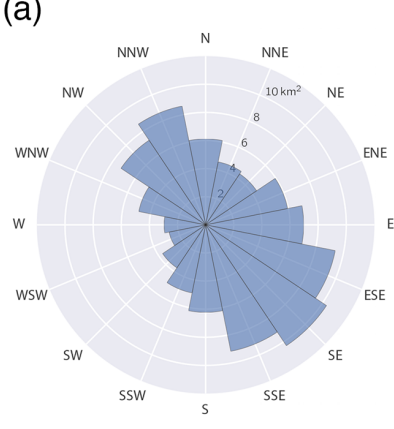

(b)

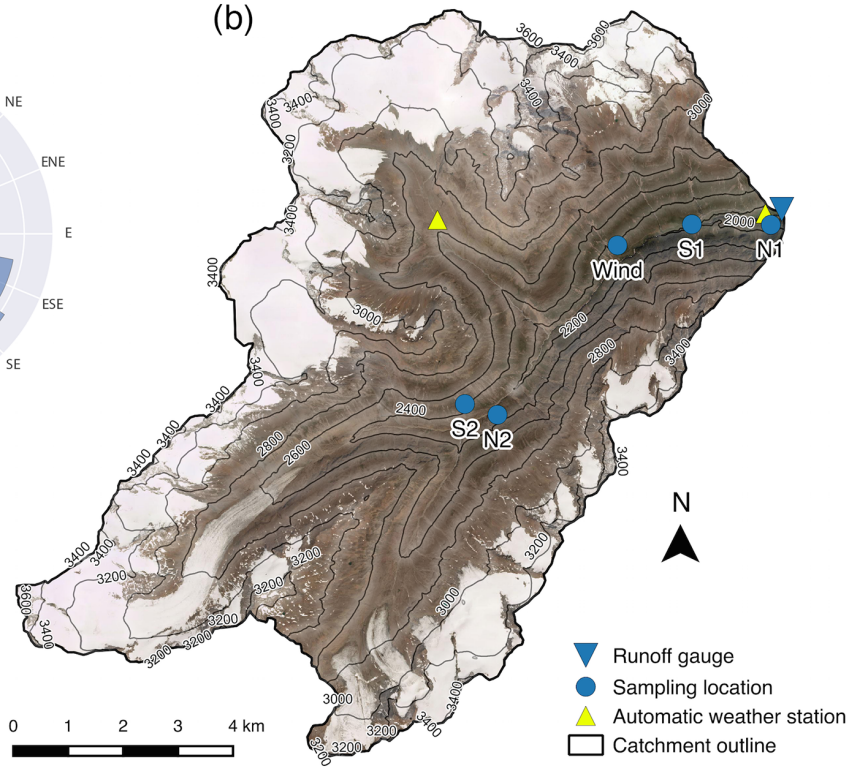

Figure 1. (a) Distribution of slope aspects in the study area; (b) study area (Rofen valley) with underlying orthophoto, sampling, and measurement locations.

\section{Study area}

The $98 \mathrm{~km}^{2}$ high-elevation catchment of the Rofenache stream is located in the central eastern Alps (Oetztal Alps, Austria), close to the main Alpine ridge. The basin ranges in elevation from approximately 1900 to 3770 m.a.s.l. The average slope is $25^{\circ}$ and the average elevation is 2930 m.a.s.l. (calculated from a $50 \mathrm{~m}$ digital elevation model). A narrow riparian zone $(<100 \mathrm{~m}$ width) is located in the valley floor. The predominantly south- (southeast) and north-facing (north-northwest) slopes form the main valley (Fig. 1a), which trends roughly from southwest to northeast (Fig. 1b). The study area has a dry inner-alpine climate. Mean annual precipitation is $800 \mathrm{~mm} \mathrm{yr}^{-1}$, of which $44 \%$ falls as snow. The mean annual temperature at the gauging station in Vent (1890 m.a.s.l., reference period: $1982-2003$ ) is $2^{\circ} \mathrm{C}$. Seasonal snow cover typically lasts from October to the end of June at the highest regions of the valley.

The bedrock consists of mainly paragneiss and mica schist and is overlain by a mantle of glacial deposits and thin soils $(<1 \mathrm{~m})$. The bedrock outcrops and unconsolidated bare rocks cover the largest part (42\%) of the catchment (CLC, 2006). Glaciers cover approximately a third of the Rofenache catchment $(35 \%)$, while pastures and coniferous forests are located in the lowest parts of the catchment and cover less than $0.5 \%$ (CLC, 2006). Sparsely vegetated areas and natural grassland cover 15 and $7.5 \%$, respectively (CLC, 2006). Besides seasonally frozen ground at slopes of various expositions, permafrost is likely to occur at an elevation over 2600 m.a.sl. at the north-facing slopes (Haeberli, 1975). The annual hydrograph reveals a highly seasonal flow regime.
The mean annual discharge is $4.5 \mathrm{~m}^{3} \mathrm{~s}^{-1}$ (reference period: 1971-2009) and is dominated by snow and glacier melt during the ablation season, which typically lasts from May to September. The onset of the early snowmelt season in the lower part of the basin is typically in April.

\section{Methods}

\subsection{Field sampling, measurements, and laboratory analysis}

The field work was conducted during the 2014 snowmelt season between the beginning of April and the end of June. Two short-term melt events ( 3 days) were investigated to illustrate the difference between early spring season melt and peak melt. The events were defined as warm and precipitation-free spells, with clear skies and dry antecedent conditions (i.e., no precipitation was observed $48 \mathrm{~h}$ prior to the event). Low discharge and air temperatures with a small diurnal variation and low melt rates, as well as a snow-covered area (SCA) of about $90 \%$ in the basin (Fig. 2a), characterize the conditions of the early melt event at the end of April (Fig. 3b). In contrast, the peak melt period at the end of June is characterized by high discharge and melt rates, a flashy hydrograph, high air temperatures with remarkable diurnal variations (Fig. 3c), and a strongly retreated snow line (SCA: 66\%; Fig. 2c). Discharge data are available at an hourly resolution for the gauging station in Vent and meteorological data are obtained by two automatic weather stations (hourly resolution) located in and around the basin (Fig. 1). 

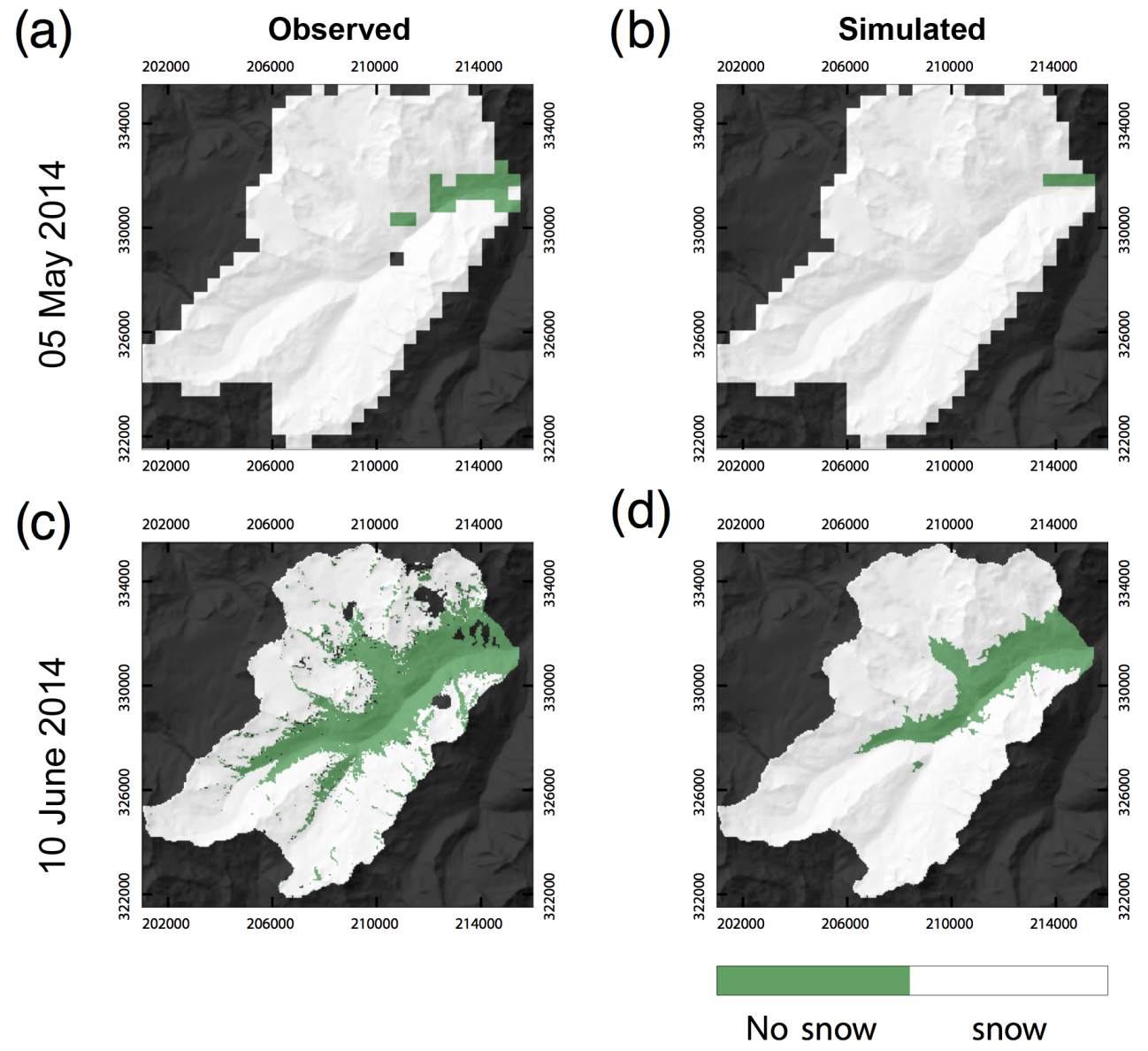

Figure 2. Comparison of observed and simulated snow distributions for (a, b) 5 May (MODIS scene) and (c, d) 10 June 2014 (Landsat scene).

The stream water sampling for stable isotope analysis consisted of pre-freshet baseflow samples at the beginning of March, sub-daily samples (temporal resolution ranges between 1 and $4 \mathrm{~h}$ ) during the two studied events and a postevent sample in July as indicated in Fig. 3a (gray-shaded area). Samples of snowmelt, snowpack, and surface overland flow (if observed) were collected at the south- (S1, S2) and north-facing slope (N1, N2), as well as on a windexposed ridge (Fig. 1b) using a snowmelt collector. At each test site, a snow pit was dug to install a $0.1 \mathrm{~m}^{2}$ polyethylene snowmelt collector at the ground-snowpack interface. The snowmelt collector consists of a pipe that drains the percolating meltwater into a fixed plastic bag. Tests yield a preclusion of evaporation for this sampling method. Composite daily snowmelt water samples (bulk sample) were collected in these bags and transferred to polyethylene bottles in the field before the onset of the diurnal melt cycle. Furthermore, sub-daily grab melt samples were collected at S1 (on 23 April) and at N2 (on 7 June) to define the diurnal variability of the respective melt event. Unfortunately further sub-daily snowmelt sampling was not feasible. The pit face was covered with white styrofoam to protect it from direct sunlight. Stream, surface overland flow, and grab snowmelt water samples were collected in $20 \mathrm{~mL}$ polyethylene bottles. Snow samples from snow pit layers were filled in airtight plastic bags and melted below room temperature before being transferred into bottles. Overall, 144 samples were taken during the study period. Snow water equivalent (SWE), snow height, snow density, and various snowpack observations (wetness and hand hardness index) were observed before the onset of the diurnal melt cycle at the study plots (Fig. 1). Mean SWE was determined by averaging five snowtube measurements within an area of $20 \mathrm{~m}^{2}$ at each site. Daily melt rates were calculated by subtracting succeeding SWE values. Sublimation was neglected, as it contributes only a small percentage $(\sim 10 \%)$ to the seasonal water balance in high-altitude catchments in the Alps (Strasser et al., 2008).

All samples were treated by the guidelines proposed by Clark and Fritz (1997) and were stored in the dark and kept cold until analysis. The isotopic composition of the samples $\left(\delta^{18} \mathrm{O}, \delta \mathrm{D}\right)$ was measured with cavity ring-down spectroscopy (Picarro L1102-i). Results are expressed in the delta notation as parts per thousand relative to the Vienna Standard Mean Ocean Water (VSMOW2). The mean laboratory pre- 

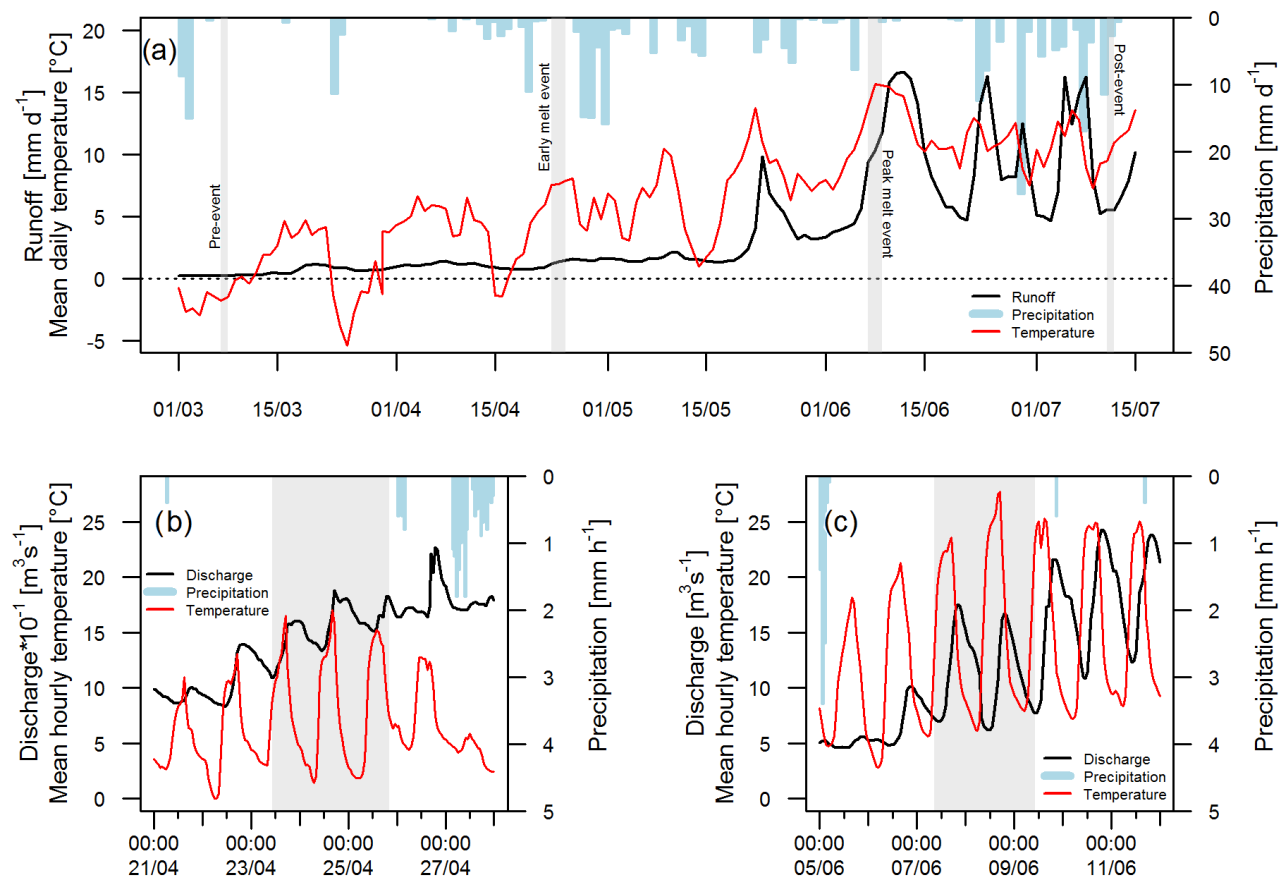

Figure 3. (a) Daily precipitation, air temperature, and discharge at the outlet of the catchment during the complete study period; hourly hydroclimatologic data of a 7-day period around the (b) early melt and (c) peak melt event. Gray-shaded areas indicate the investigated events.

cision (replication of eight measurements) for all measured samples was $0.06 \%$ for $\delta^{18} \mathrm{O}$. Due to the covariance of $\delta^{2} \mathrm{H}$ $(\delta \mathrm{D})$ and $\delta^{18} \mathrm{O}$ (Fig. 5), all analyses were done with oxygen18 values.

\subsection{Model description}

For the simulation of the daily melt rates, the non-calibrated, distributed, and physically based hydroclimatological model AMUNDSEN (Strasser, 2008) was applied. Model features include interpolation of meteorological fields from point measurements (Marke, 2008; Strasser, 2008); simulation of shortwave and longwave radiation, including topographic and cloud effects (Corripio, 2003; Greuell et al., 1997); parameterization of snow albedo depending on snow age and temperature (Rohrer, 1991); modeling of forest snow and meteorological processes (Liston and Elder, 2006; Strasser et al., 2011); lateral redistribution of snow due to gravitational(Gruber, 2007) and wind-induced (Helfricht, 2014; Warscher et al., 2013) processes; and determination of snowmelt using an energy balance approach (Strasser, 2008). Besides having been applied for various other Alpine sites in the past (Hanzer et al., 2014; Marke et al., 2015; Pellicciotti et al., 2005; Strasser, 2008; Strasser et al., 2004, 2008), AMUNDSEN has recently been set up and extensively validated for the Oetztal Alps region (Hanzer et al., 2016). This setup was also used to run the model in this study for the period 2013-2014 using a temporal resolution of $1 \mathrm{~h}$ and a spatial resolution of $50 \mathrm{~m}$. In order to determine the model performance during the study period, catchment-scale snow distribution by satellite-derived binary snow-cover maps and plotscale observed SWE data were used for the validation (cf. Sect. 4.2). Therefore, the spatial snow distribution as simulated by AMUNDSEN was compared with a set of MODIS (500 $\mathrm{m}$ spatial resolution) and Landsat (30 $\mathrm{m}$ resolution, subsequently resampled to the $50 \mathrm{~m}$ model resolution) snow maps with less than $10 \%$ cloud coverage over the study area using the methodology described in Hanzer et al. (2016). Model results were evaluated using the performance measures BIAS, accuracy (ACC) and critical success index (CSI) (Zappa, 2008). ACC represents the fraction of correctly classified pixels (either snow covered or snow free both in the observation and the simulation). CSI describes the number of correctly predicted snow-covered pixels divided by the number of times where snow is predicted in the model and/or observed, and BIAS corresponds to the number of snowcovered pixels in the simulation divided by the respective number in the observation. ACC and CSI values range from 0 to 1 (where 1 is a perfect match), while BIAS values below 1 indicate underestimations of the simulated snow cover, and values above 1 indicate overestimations. At the plot-scale, observed SWE values were compared with AMUNDSEN SWE values represented by the underlying pixels at the location of the snow course. Catchment-scale melt rates are calculated by subtracting two consecutive daily SWE grids, neglecting sublimation losses, which is also done to achieve 
observed melt rates at the plot scale. Subsequently, the digital elevation model was used to calculate an aspect grid and further to divide the catchment into two parts: grid cells with aspects ranging from $\geq 270$ to $\leq 90^{\circ}$ were classified as "north facing", while the remaining cells were attributed to the class "south facing". Finally, these two grids were combined to derive melt rates for the south-facing $\left(\right.$ melt $\left._{\mathrm{s}}\right)$ and for the northfacing slope $\left(\right.$ melt $\left._{n}\right)$.

\subsection{Isotopic hydrograph separation, weighting approaches, and uncertainty analysis}

IHS is a steady-state tracer mass balance approach, and several assumptions underlie this simple principle, which are described and reviewed in Buttle (1994) and Klaus and McDonnell (2013):

1. The isotopic compositions of event and pre-event water are significantly different.

2. The event water isotopic signature has no spatiotemporal variability, or variations can be accounted for.

3. The pre-event water isotopic signature has no spatiotemporal variability, or variations can be accounted for.

4. Contributions from the vadose zone must be negligible or soil water should be isotopically similar to groundwater.

5. There is no or minimal discharge contribution from surface storage.

The focus of this study is on one of the assumptions: the spatiotemporal variability of the event water isotopic signature is absent or can be accounted for. The fraction of event water $\left(f_{\mathrm{e}}\right)$ contributing to streamflow was calculated from Eq. (1).

$f_{\mathrm{e}}=\frac{\left(C_{\mathrm{p}}-C_{\mathrm{s}}\right)}{\left(C_{\mathrm{p}}-C_{\mathrm{e}}\right)}$

The tracer concentration of the pre-event component $\left(C_{\mathrm{p}}\right)$ is the $\delta^{18} \mathrm{O}$ composition of baseflow prior to the onset of the freshet period, constituted mainly by groundwater and potentially by soil water, which was assumed to have the same isotopic signal as groundwater. Tracer concentration $C_{\mathrm{s}}$ is the isotopic composition of stream water for each sampling time. The isotopic compositions of snowmelt samples were weighted differently to obtain the event water tracer concentration $\left(C_{\mathrm{e}}\right)$ using the following five weighting approaches:

1. volume weighted with observed plot-scale melt rates (VWO);

2. equally weighted, assuming an equal melt rate on northand south-facing slopes (VWE);
3. no weighting, only south-facing slopes considered (SOUTH);

4. no weighting, only north-facing slopes considered (NORTH);

5. volume weighted with simulated catchment-scale melt rates (VWS).

Equation (2) is the VWS approach with simulated melt rates for north- and south-facing slope as described in Sect. 3.2, where $M$ is the simulated melt rate (in $\mathrm{mm} \mathrm{d}^{-1}$ ), $\delta^{18} \mathrm{O}$ is the isotopic composition of sampled snowmelt, and subscripts $\mathrm{s}$ and $\mathrm{n}$ indicate north and south, respectively. For obtaining the value of $C_{\mathrm{e}}$ a daily time step $(t)$ is used, considering daily melt rates and the isotopic composition of the daily bulk snowmelt samples.

$C_{\mathrm{e}}(t)=\frac{M_{\mathrm{S}}(t) \delta^{18} \mathrm{O}_{\mathrm{s}}(t)+M_{\mathrm{n}}(t) \delta^{18} \mathrm{O}_{\mathrm{n}}(t)}{M_{\mathrm{S}}(t)+M_{\mathrm{n}}(t)}$

An uncertainty analysis (Eq. 3) was performed according to the Gaussian standard error method proposed by Genereux (1998):

$W_{f_{\mathrm{e}}}=\left\{\left[\frac{C_{\mathrm{p}}-C_{\mathrm{s}}}{\left(C_{\mathrm{p}}-C_{\mathrm{e}}\right)^{2}} W_{C_{\mathrm{e}}}\right]^{2}+\left[\frac{C_{\mathrm{s}}-C_{\mathrm{e}}}{\left(C_{\mathrm{p}}-C_{\mathrm{e}}\right)^{2}} W_{C_{\mathrm{p}}}\right]^{2}+\left[\frac{-1}{\left(C_{\mathrm{p}}-C_{\mathrm{e}}\right)^{2}} W_{C_{\mathrm{s}}}\right]^{2}\right\}^{1 / 2}$,

where $W$ is the uncertainty, $C$ is the isotopic composition, $f$ is the fraction, and the subscripts $\mathrm{p}, \mathrm{s}$, and e refer to the pre-event, stream, and event component, respectively. This assumes negligible errors in the discharge measurements and the melt rates (modeled and observed). The uncertainty of streamflow $\left(W_{C_{\mathrm{s}}}\right)$ is assumed to be equal to the laboratory precision $(0.06 \%)$ ). For the uncertainty of the event component $\left(W_{C_{\mathrm{e}}}\right)$, the diurnal temporal variability (standard deviation) of the snowmelt isotopic signal (from one site and 1 day) was multiplied by the appropriate value of the two-tailed $\mathrm{t}$-table (dependent on sample number) and used for the event, as proposed by Genereux (1998). This resulted in different uncertainty values for the early melt event $\left(W_{C_{\mathrm{e}}}=0.2 \%\right.$ ) and the peak melt event $\left(W_{C_{\mathrm{e}}}=0.5 \%\right.$ ). An error of $0.04 \%$ o was assumed for the pre-event component $\left(W_{C_{\mathrm{p}}}\right)$, which reflects the standard deviation of two baseflow samples. A $95 \%$ confidence level was used. Spatial variation in snowmelt and its isotopic composition were not considered in this error calculation method as they represent the hydrologic signal of interest.

\section{Results}

\subsection{Spatiotemporal variability of streamflow and stable isotopic signature of sampled of water sources}

Two major snowmelt pulses (mid-May and beginning of June) and four less pronounced pulses between mid-March 

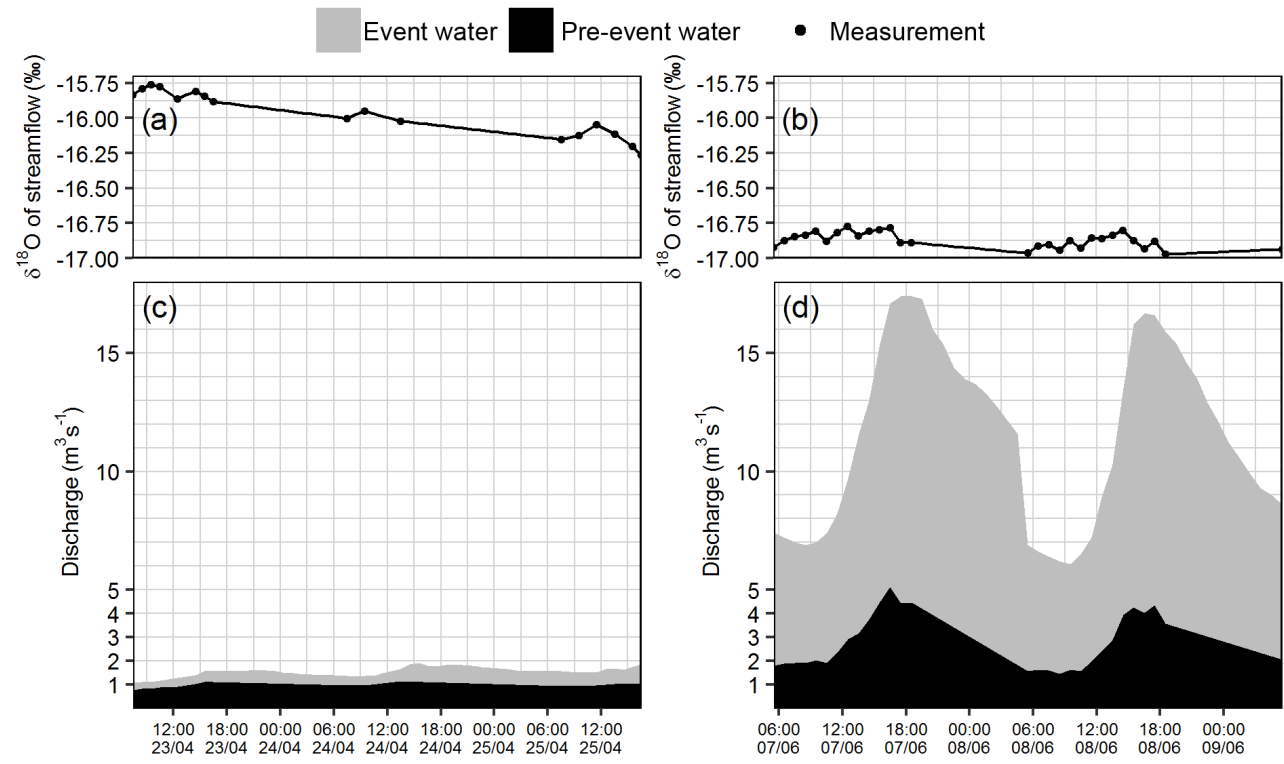

Figure 4. Linearly interpolated stream isotopic content of Rofenache for (a) the early melt and (b) the peak melt event. Dots indicate measurements. Event and pre-event water contributions during (c) the early melt and (d) the peak melt event calculated with the VWS approach.

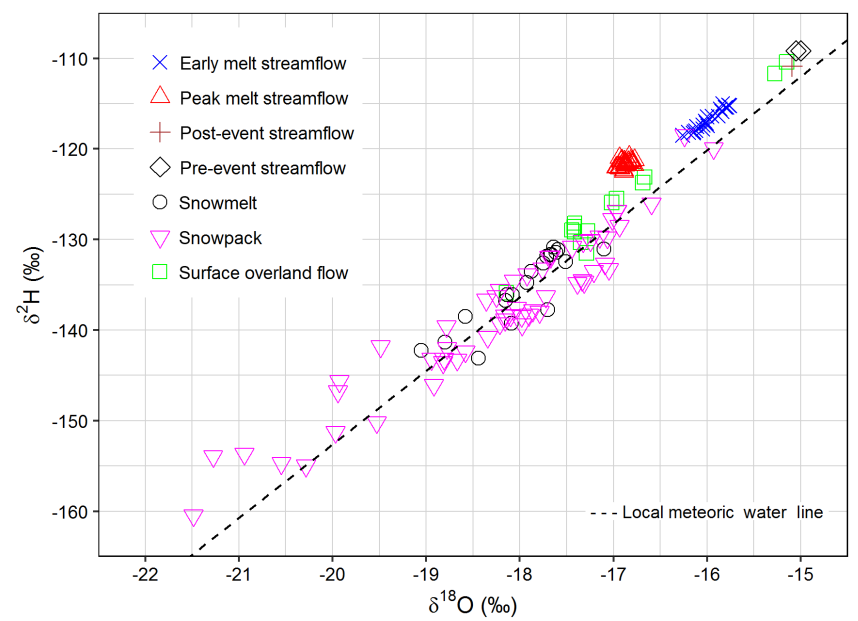

Figure 5. Relationship between $\delta^{2} \mathrm{H}$ and $\delta^{18} \mathrm{O}$ of water sources sampled during the snowmelt season of 2014 in the Rofen valley, Austrian Alps.

to early May occurred during the snowmelt season (Fig. 3a). Peak melt occurred at the beginning of June with maximum daily temperatures and runoff of $15^{\circ} \mathrm{C}$ and $18 \mathrm{~mm} \mathrm{~d}^{-1}$, respectively. The following high flows were affected by rain (Fig. 3a) and glacier melt due to the strongly retreated snow line and snow-free ablation area of the glaciers in July. Diurnal variations in discharge were strongly correlated with diurnal variations in air temperature (Fig. $3 b$ and c) with a time lag of $3-5 \mathrm{~h}$ for the early melt event and $2-3 \mathrm{~h}$ for the peak melt event. An inverse relationship between stream- flow $\delta^{18} \mathrm{O}$ and discharge was found for the early melt event (Fig. 4a and c). Small diurnal responses of streamflow $\delta^{18} \mathrm{O}$ were identified for both events, but were masked due to missing data during the recession of the hydrograph.

The quality control of the isotopic data was performed by the $\delta^{2} \mathrm{H}-\delta^{18} \mathrm{O}$ plot (Fig. 5), which indicated no shift in the linear regression line and thus no secondary fractionation effects (evaporation) during storage and transport of the samples. The slope of the linear regression (slope $=8.5, n=144$, $\left.R^{2}=0.93\right)$ of the measurement data slightly deviates from that of the global meteoric (slope $=8$ ) and local meteoric water line (slope $=8.1$ ) based on monthly data from the Austrian Network of Isotopes in Precipitation sampling site in Obergurgl, which is located in an adjacent valley (reference period: 1991-2014). The small deviation (visible in Fig. 5) of the sampled water (i.e., snowpack and snowmelt) could indicate fractionation effects induced by phase transition (i.e., melt/refreeze and sublimation). The significant differences between the isotopic signatures of pre-event streamflow and snowmelt water enabled the IHS.

Overall, the $\delta^{18} \mathrm{O}$ values ranged from -21.5 to $-15.0 \%$, while snowpack samples were characterized by the most negative and pre-event baseflow samples by the least negative values. Snowpack samples showed a wide isotopic range, while streamflow samples revealed the narrowest spread, reflecting a composite isotopic signal mixing of the water components. Figure 6 shows the $\delta^{18} \mathrm{O}$ data of the water samples grouped into different categories and split into early and peak melt data. It shows the different $\delta^{18} \mathrm{O}$ ranges and medians of the sampled water sources (Fig. 6a), as well as marked spatiotemporal variations in the isotopic signal (Fig. $6 \mathrm{~b}$ and c). 

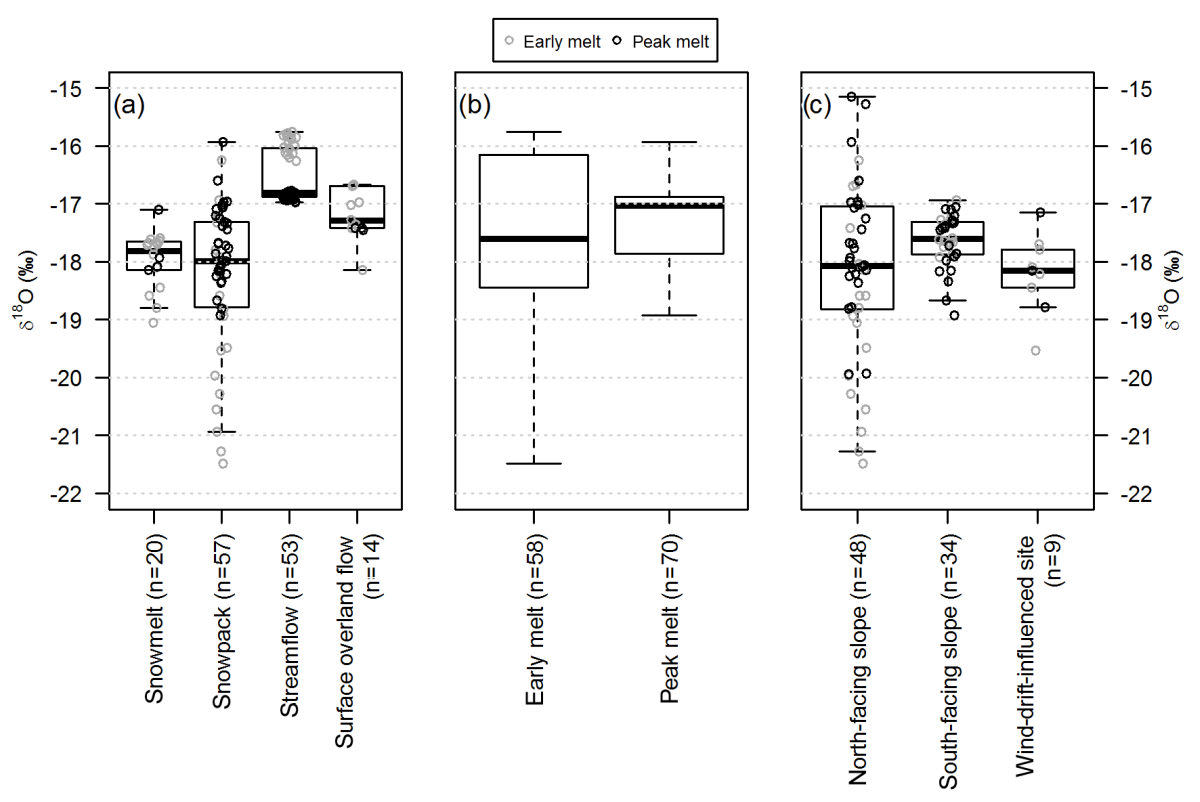

Figure 6. Jittered dot plots for $\delta^{18} \mathrm{O}$ of collected water samples split into (a) water sources, (b) stage of snowmelt and (c) spatial origin. Gray circles indicate early melt samples and black circles peak melt samples. The gray and black line represents the median of early and peak melt data, respectively. $n_{\mathrm{e}}$ is the number of early melt samples and $n_{\mathrm{p}}$ is the number of peak melt samples.

It is apparent that the snowpack $\delta^{18} \mathrm{O}$ values have a larger variation compared to the snowmelt data due to homogenization effects (Fig. 6a), as was also shown by Árnason et al. (1973), Dinçer et al. (1970) and Stichler (1987). The median of the $\delta^{18} \mathrm{O}$ of snowmelt was higher than that of the snowpack, which indicates fractionation. The median $\delta^{18} \mathrm{O}$ of surface overland flow was higher than that of snowmelt (Fig. 6a) for the early and peak melt period. Overall, the peak melt $\delta^{18} \mathrm{O}$ values (Fig. 6b) were less variable and had a higher median than the early melt values, because fractionation effects (due to melt/refreeze and sublimation) most likely altered the isotopic composition of the snowpack over time (cf. Taylor et al., 2001, 2002). One major finding was that the $\delta^{18} \mathrm{O}$ values on the north-facing slope had a larger range and a lower median compared to the opposing slope (Fig. 6c). Samples from the wind-drift-influenced site (also south exposed) were more depleted in heavy isotopes compared to the south-facing slope samples (Fig. 6c).

In general, the average snowmelt and snowpack isotopic composition was more depleted for the early melt period (Table 1) and changed over time because fractionation likely altered the snowpack and its melt. It is obvious that the isotopic evolution (gradually enrichment) on the south-facing slope took place earlier in the annual melting cycle of the snow, and indicates a premature snowpack concerning the enrichment of isotopes and earlier ripening compared to the north-facing slope.

Table 1 shows that meltwater sampling throughout the entire snowmelt period is required to account for the temporal variation in the isotopic composition of the snowpack (cf. Taylor et al., 2001, 2002). In detail, the snowpack and snowmelt $\delta^{18} \mathrm{O}$ data highlighted a marked spatial inhomogeneity between north- and south-facing slopes throughout the study period. The snowpack isotopic composition from both sampled slopes was statistically different for the early melt, but not for the peak melt (with Kruskal-Wallis test at 0.05 significance level), whereas the snowmelt $\delta^{18} \mathrm{O}$ showed a significant difference throughout the study period (Fig. 7).

Sub-daily snowmelt samples $(n=5)$ at S1 (23 April 2014) had a range of $0.1 \% \circ$ in $\delta^{18} \mathrm{O}$, and the bulk sample (integrating the entire diurnal melt cycle) was within the scatter of those values (Fig. 8). The intra-daily variability of snowmelt $(n=3)$ at $\mathrm{N} 2$ (7 June 2014) was relatively higher with values ranging from -17.9 to $-18.1 \%$. The bulk sample $(-17.9 \%$ ) was at the upper end of those values (Fig. 8).

Stream water isotopic composition was more enriched in heavy isotopes during the early melt period and successively became more depleted throughout the freshet period, resulting in more negative values during peak melt (Table 2). The standard deviation and range of stream water $\delta^{18} \mathrm{O}$ during early melt was higher and could be related to an increasing snowmelt contribution throughout the event and larger diurnal amplitudes of snowmelt contribution compared to peak melt (Table 2).

\subsection{Snow model validation and snowmelt variability}

Figure 9 shows the values for the selected performance measures based on the available MODIS and Landsat scenes during the period March-July 2014. The results indicate a 
Table 1. Average isotopic composition of snowpack and snowmelt with standard deviation for north- and south-facing slopes during the early and the peak melt event. Values are averages of 3 consecutive days.

\begin{tabular}{lll|ll}
\hline & \multicolumn{2}{c|}{ North-facing slope } & \multicolumn{2}{c}{ South-facing slope } \\
\cline { 2 - 5 } & Snowpack $\delta^{18} \mathrm{O}(\%)$ & Snowmelt $\delta^{18} \mathrm{O}(\%)$ & Snowpack $\delta^{18} \mathrm{O}(\%)$ & Snowmelt $\delta^{18} \mathrm{O}(\% \circ)$ \\
\hline Early melt event & $-19.7 \pm 0.6(n=12)$ & $-18.8 \pm 0.2(n=3)$ & $-17.3 \pm 0.3(n=4)$ & $-17.4 \pm 0.2(n=8)$ \\
Peak melt event & $-17.6 \pm 0.4(n=18)$ & $-17.9 \pm 0.1(n=3)$ & $-17.9 \pm 0.1(n=15)$ & $-17.1 \pm 0.0(n=2)$ \\
\hline
\end{tabular}

Table 2. Descriptive statistics of streamflow isotopic composition at the outlet of the Rofenache during events of the snowmelt season 2014.

\begin{tabular}{lrrrr}
\hline & Pre-event & Early melt & Peak melt & Post-event \\
\hline Date & $7 \mathrm{Mar}$ & $23-25 \mathrm{Apr}$ & $7-9 \mathrm{Jun}$ & 11 Jul \\
Average $\left(\delta^{18} \mathrm{O} \% 0\right)$ & -15.02 & -15.97 & -16.87 & -15.09 \\
Standard deviation $\left(\delta^{18} \mathrm{O} \%\right.$ o $)$ & 0.04 & 0.16 & 0.05 & - \\
Range $\left(\delta^{18} \mathrm{O} \%\right.$ o $)$ & 0.05 & 0.50 & 0.20 & - \\
Number of samples & 2 & 17 & 30 & 1 \\
\hline
\end{tabular}

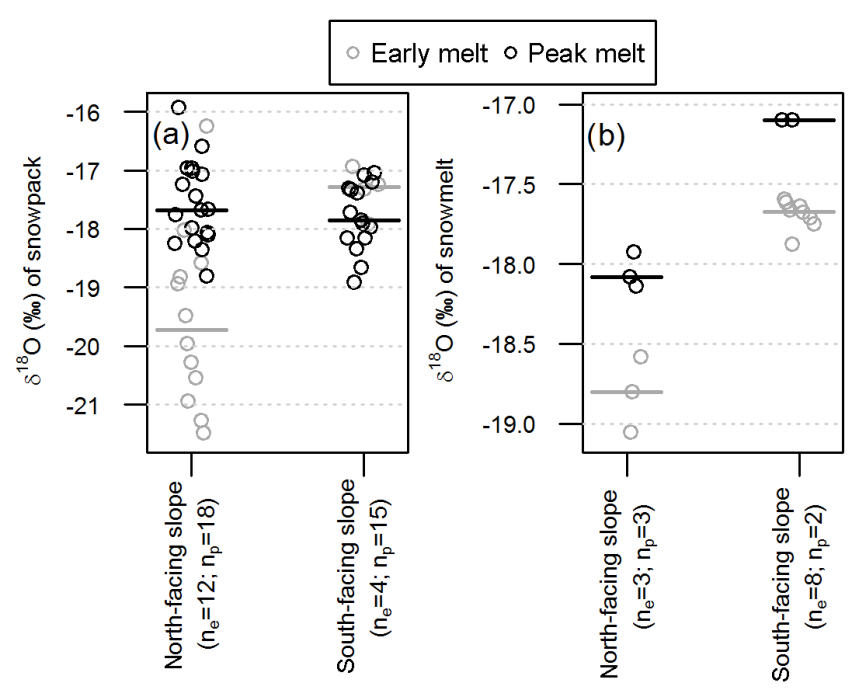

Figure 7. Jittered dot plots for $\delta^{18} \mathrm{O}$ of (a) snowpack and (b) snowmelt of north- and south-facing slopes. Gray circles indicate early melt samples and black circles are for peak melt samples. The gray and black lines indicates the median of the early and peak melt data, respectively. $n_{\mathrm{e}}$ is the number of early melt samples and $n_{\mathrm{p}}$ is the number of peak melt samples.

reasonable model performance with a tendency to slightly overestimate the snow cover during the peak melt season (BIAS > 1). In general the CSI does not drop below 0.7, and $80 \%$ of the pixels are correctly classified (ACC) throughout the study period. Figure 2 shows the observed and simulated spatial snow distribution around the time of the two events. Despite a higher SCA during the early melt season (Fig. 2a and b) compared to the peak melt season (Fig. 2c and d) one can see the overestimation of the simulated SCA compared to the observed (MODIS/Landsat) SCA. Table 3

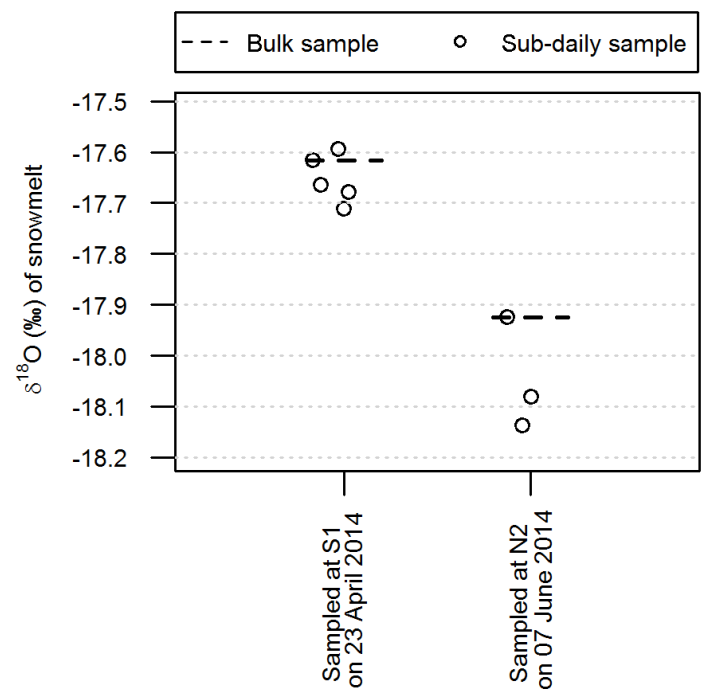

Figure 8. Comparison of snowmelt $\delta^{18} \mathrm{O}$ between the bulk sample (dashed line) and sub-daily samples (circles) for the two sites (S1, N2).

shows the observed and simulated SWE values at the plot scale. The model slightly underestimated SWE during peak melt, but generally appears to be in quite good agreement, suggesting well-simulated snowpack processes. Throughout the study period the model deviates by $13 \%$ from the observed SWE values, but the representativeness (small-scale effects) of SWE values for the respective $50 \mathrm{~m}$ pixels should be considered.

Snowmelt (observed and simulated daily losses of SWE) showed a distinct spatial variation between the north-facing and the south-facing slope for the early melt (23/24 April) period, but less marked variations for the peak melt (7/8 June) period (Fig. 10). Relative day-to-day differences are more 
Table 3. Comparison of observed and simulated (represented by the underlying pixel) SWE values.

\begin{tabular}{|c|c|c|c|c|c|}
\hline \multirow[t]{2}{*}{ Site } & \multirow[t]{2}{*}{ Date } & \multirow{2}{*}{$\begin{array}{l}\text { Stage of } \\
\text { snowmelt } \\
\text { season }\end{array}$} & \multicolumn{2}{|c|}{ SWE [mm] } & \multirow{2}{*}{$\begin{array}{r}\text { Difference between } \\
\text { observed and } \\
\text { simulated SWE [\%] }\end{array}$} \\
\hline & & & Observed & Simulated & \\
\hline S1 & 23 Apr 2014 & Early melt & 141 & 151 & 7 \\
\hline N1 & 23 Apr 2014 & Early melt & 351 & 356 & 1 \\
\hline Wind & 24 Apr 2014 & Early melt & 201 & 229 & 14 \\
\hline $\mathrm{S} 1$ & 25 Apr 2014 & Early melt & 113 & 78 & -31 \\
\hline N1 & 25 Apr 2014 & Early melt & 270 & 293 & 9 \\
\hline $\mathrm{N} 2$ & 7 Jun 2014 & Peak melt & 594 & 477 & -20 \\
\hline $\mathrm{N} 2$ & 8 Jun 2014 & Peak melt & 568 & 435 & -23 \\
\hline $\mathrm{N} 2$ & 9 Jun 2014 & Peak melt & 537 & 390 & -27 \\
\hline \multicolumn{5}{|c|}{ Mean deviation between observed and simulated SWE } & 13 \\
\hline
\end{tabular}

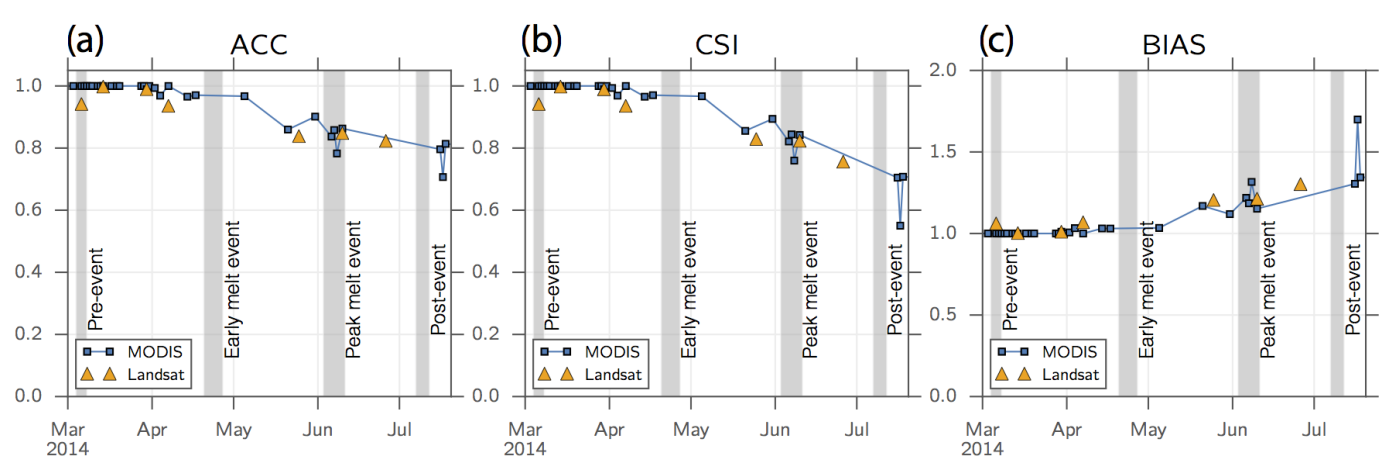

Figure 9. Performance measures of (a) accuracy (ACC), (b) critical success index (CSI), and (c) BIAS as calculated by comparing AMUNDSEN simulation results with satellite-derived (MODIS/Landsat) snow maps.

pronounced for the early melt season. Both simulated and observed melt rates are higher for the peak melt event on the south-facing slope, but not for the north-facing slope. Simulated melt intensity on the south-facing slope at the end of April was twice the rate on the north-facing slope, while simulated melt rates were approximately the same for the opposing slopes during peak melt. Simulated (catchment scale) snowmelt rates were markedly lower during the early melt (23 and 24 April) on the north-facing slope compared to the observed (plot scale) melt rates (Fig. 10a), but differences between them were small during peak melt for both slopes ( 7 and 8 June; Fig. 10).

\subsection{Weighting techniques and isotope-based hydrograph separation}

Differences between the applied snowmelt weighting techniques, induced by the high spatial variability of snowmelt (Sect. 4.2), led to different event water isotopic compositions $\left(C_{\mathrm{e}}\right)$ for the IHS analyses (Table 4$)$. The event water component was depleted in $\delta^{18} \mathrm{O}$ by roughly $0.3 \%$ for the second day (24 April) of the early melt event compared to the preceding day, but inter-daily variation during the peak melt is
Table 4. Isotopic composition of the event water component for the applied weighting techniques.

\begin{tabular}{lrrrr}
\hline & \multicolumn{4}{c}{ Event water isotopic composition } \\
& \multicolumn{4}{c}{$\left(\delta^{18} \mathrm{O} \%\right)$} \\
\cline { 2 - 5 } & $23 \mathrm{Apr}$ & 24 Apr & 7 Jun & 8 Jun \\
\hline VWS & -17.9 & -18.2 & -17.5 & -17.5 \\
VWO & -18.3 & -18.6 & -17.4 & -17.5 \\
VWE & -18.1 & -18.3 & -17.5 & -17.5 \\
NORTH & -18.6 & -18.8 & -17.9 & -17.9 \\
SOUTH & -17.6 & -17.9 & -17.1 & -17.1 \\
\hline
\end{tabular}

almost absent. Especially during early melt (23 to 24 April), strong deviations between observed plot-scale melt rates and distributed (areal) melt rates obtained by AMUNDSEN occurred (Fig. 11), and led to more different event water isotopic compositions between the VWS and the VWO approach (Table 4).

The hydrograph and the results of the IHS applied with the VWS method for the early and peak melt event are presented in Fig. 4 and highlight the lower flow rates and higher pre- 


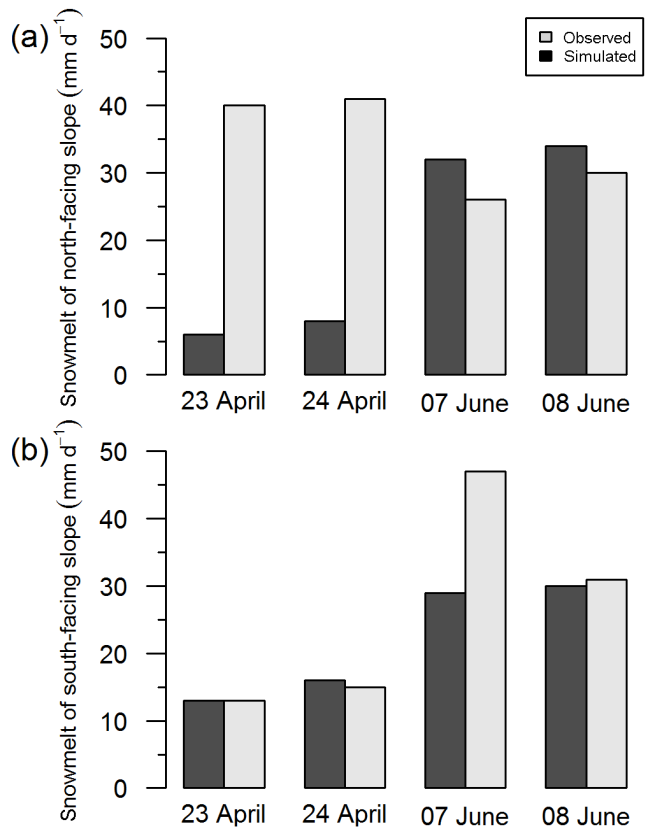

Figure 10. Observed (plot scale) and simulated (catchment scale) daily snowmelt on (a) the north-facing and (b) the south-facing slope for the early melt (23/24 April) and peak melt (7/8 June).

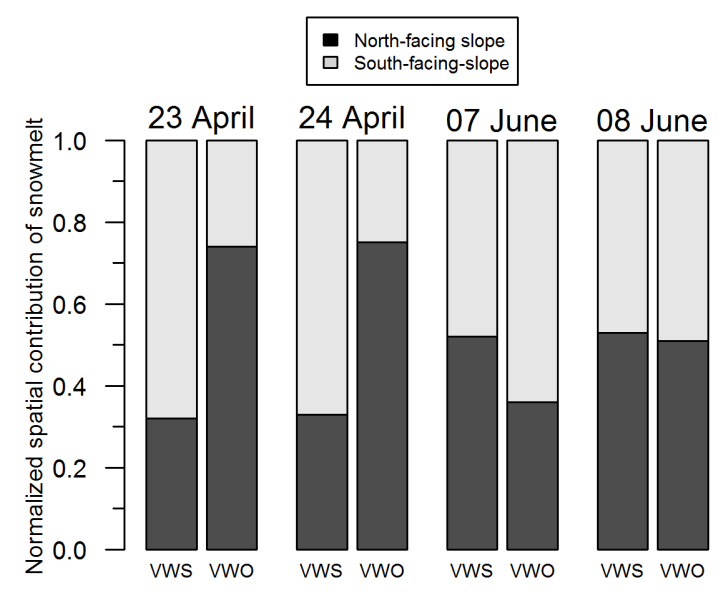

Figure 11. Relative contribution of the north- and south-facing slope $\delta^{18} \mathrm{O}$ values to the catchment average. VWS: volume weighted with simulated (areal) melt rates. VWO: volume weighted with observed (plot-scale) melt rates.

event fractions during early melt (Fig. 4c) and vice versa for the peak melt period (Fig. 4d). The total runoff volume during the peak melt period was approximately 6 times higher than in the early melt period. The fractions of snowmelt (volume) estimated with the VWS approach were 35 and $75 \%$ with calculated uncertainties (95\% confidence level) of \pm 3 and $\pm 14 \%$ for the early and peak melt event, respectively. The uncertainty calculated from Eq. (3) of the IHS applied with the VWS method was higher $(14 \%)$ for the peak melt
Table 5. Discharge characteristics of the Rofenache for the early and peak melt event.

\begin{tabular}{lrr}
\hline & \multicolumn{2}{c}{ Event } \\
\cline { 2 - 3 } & \multicolumn{1}{c}{ Early melt } & Peak melt \\
\hline Date & $23-25 \mathrm{Apr}$ & $7-9 \mathrm{Jun}$ \\
Mean discharge & $1.5 \mathrm{~m}^{3} \mathrm{~s}^{-1}$ & $11.5 \mathrm{~m}^{3} \mathrm{~s}^{-1}$ \\
Peak discharge & $1.9 \mathrm{~m}^{3} \mathrm{~s}^{-1}$ & $17.4 \mathrm{~m}^{3} \mathrm{~s}^{-1}$ \\
Volume runoff & $3.3 \mathrm{~mm}$ & $20.7 \mathrm{~mm}$ \\
Mean-event water fraction & $35 \pm 3 \%$ & $75 \pm 14 \%$ \\
Peak-event water fraction & $44 \pm 4 \%$ & $78 \pm 15 \%$ \\
\hline
\end{tabular}

event than for the early melt event because the difference between isotopic composition of pre-event water and event water was smaller than for the early melt event (uncertainty: $3 \%$ ) (cf. Tables 2 and 4 ).

Throughout the early melt event, the snowmelt fraction increased from 25 to $44 \%$ (Fig. 4c; Table 5). This trend mirrors the stream isotopic composition, which became more depleted (Fig. 4a). Event water contributions during peak melt were generally higher but had a smaller range (70 to $78 \%$; Fig. 4d). Diurnal isotopic variations of stream water were small for both events (Fig. 4a and b), and could not clearly be obtained due to missing data on the falling limb of the hydrographs.

The use of the different weighting approaches led to strongly varying estimated snowmelt fractions of streamflow (Fig. 12). Especially the differences between the SOUTH and the NORTH approach during both investigated events (up to $24 \%$ ), and the differences between the VWS and the VWO approach (5\%) during early melt (Fig. 12a) are notable. Event water contributions estimated by the different weighting methods ranged from $21-28 \%$ at the beginning of the early melt event up to $31-55 \%$ at the end of the event (Fig. 12a, Table 6). Minimum event water contributions during the peak melt were estimated at $60-84 \%$ and maxima ranged between 67 and $94 \%$ for the different weighting methods (Table 6, Fig. 12b). Beside these intra-event variations in snowmelt contribution, the volumetric variations at the event-scale were smaller and ranged between $28-40$ and $66-90 \%$, for the early and peak melt event, respectively (Table 6).

Considering only spatial variation of snowmelt isotopic signatures (i.e., comparing the NORTH/SOUTH approach with the VWE approach) for IHS led to differences in estimated event water fractions up to 7 and $14 \%$ for the early and peak melt period, respectively (Table 6). However, considering only spatial variation in snowmelt rates (i.e., comparing the VWS/VWO approach with the VWE approach) led to differences in event water fraction up to 3 and $2 \%$ for the early and peak melt period, respectively (Table 6).

Surface overland flow was not considered in the IHS analyses, but if applied, it would most likely increase the cal- 
Table 6. Event water contribution to streamflow based on the different weighting techniques. The error indicates the variability (standard deviation) and the values in parentheses depict the range.

\begin{tabular}{llllll}
\hline & \multicolumn{4}{c}{ Event water contribution (\%) } \\
\cline { 2 - 6 } & VWS & VWO & VWE & NORTH & SOUTH \\
\hline Early melt event & $35 \pm 6$ & $30 \pm 4$ & $33 \pm 5$ & $28 \pm 3$ & $40 \pm 9$ \\
& $(25-44)$ & $(22-35)$ & $(24-39)$ & $(21-31)$ & $(28-55)$ \\
Peak melt event & $75 \pm 2$ & $78 \pm 3$ & $76 \pm 2$ & $66 \pm 2$ & $90 \pm 3$ \\
& $(70-78)$ & $(71-82)$ & $(70-78)$ & $(60-67)$ & $(84-94)$ \\
\hline
\end{tabular}
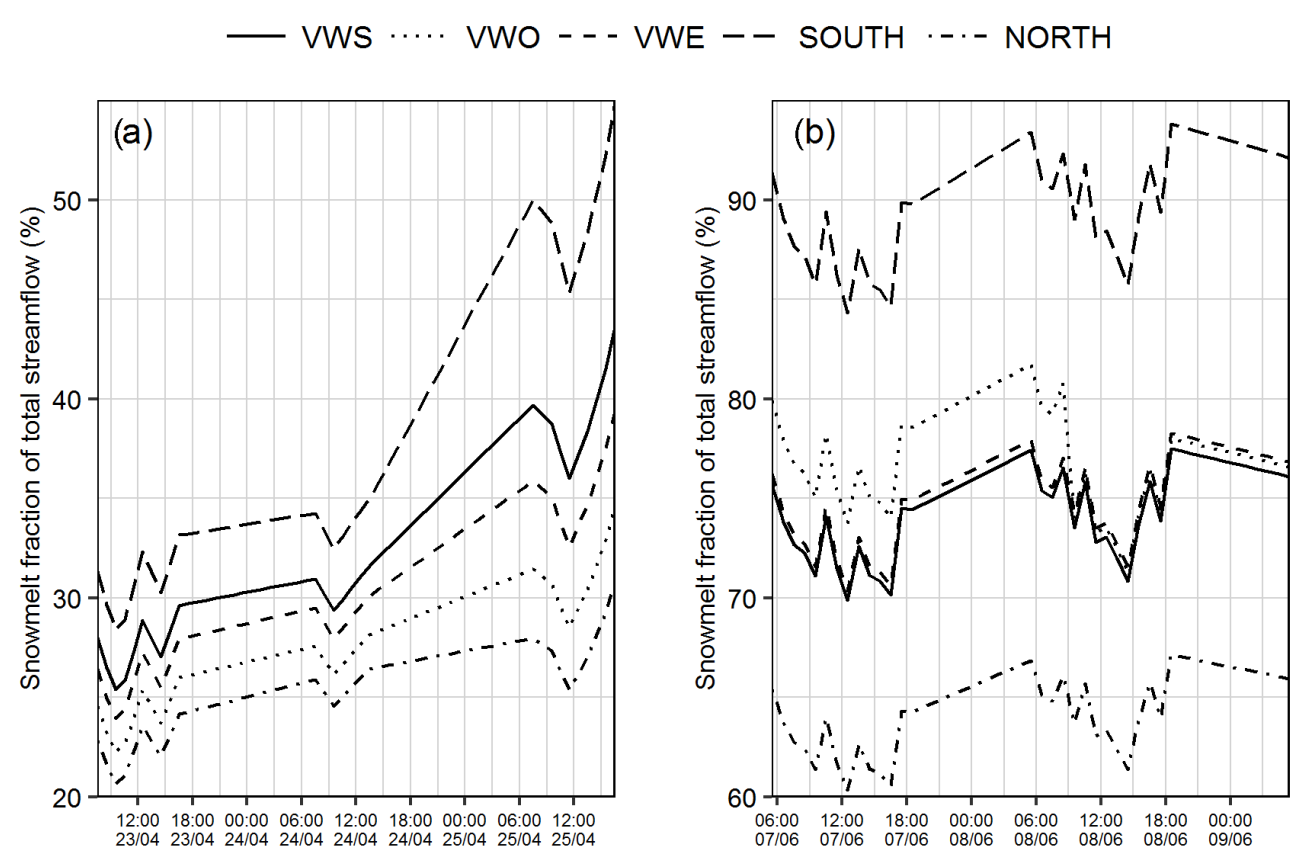

Figure 12. Comparison of the IHS results for the different weighting techniques used for (a) early melt and (b) peak melt. Scale of $y$ axis in (b) differs from that in (a).

culated snowmelt fraction slightly. Furthermore, snowmelt samples from the wind-exposed site were not used in the IHS analyses because this site was only sampled on the southfacing slope during early melt and is not representative for the catchment due to its limited coverage. However, incorporation of this data would decrease the calculated snowmelt fraction by approximately $2 \%$.

\section{Discussion}

\subsection{Temporal variation in streamflow during the melting season}

Snowmelt is a major contributor to streamflow during the spring freshet period in alpine regions and large amounts of snowmelt water infiltrate into the soil and recharge groundwater (Penna et al., 2014). The hydrological response of the stream followed the variations of air temperature, as already observed by Braithwaite and Olesen (1989) (Fig. 3a). The observed time lags (Fig. $3 \mathrm{~b}$ and c) between maximum daily air temperature and daily peak flow are common in mountain catchments (Engel et al., 2016; Schuler, 2002). During peak melt, the flashy hydrograph revealed less variation in the timing of peak discharge of 7-day data (Fig. 3c) compared to the early melt, as reported by Lundquist and Cayan (2002). The increase in discharge coincides with decreasing streamflow $\delta^{18} \mathrm{O}$ during the early melt event (Fig. $4 \mathrm{a}$ and c) and confirms the earlier findings of Engel et al. (2016), who identified inverse relationships between streamflow $\delta^{18} \mathrm{O}$ and discharge during several $24 \mathrm{~h}$ events in an adjacent valley on the southern side of the main Alpine ridge, although their findings rely on streamflow contributions from snow and glacier melt. The lower stream water isotopic composition during peak melt suggests a remarkable contribution of more depleted snowmelt to streamflow and therefore confirms the results of the IHS. 


\subsection{Spatiotemporal variability of snowmelt and its isotopic signature}

The rate of snowmelt varies spatially in catchments with complex topography (Carey and Quinton, 2004; Dahlke and Lyon, 2013; Pomeroy et al., 2003). This was also demonstrated for the Rofen valley in this study (Fig. 10, Table 3). Snowmelt results from a series of processes (e.g., energy exchange between snow-atmosphere) that are spatially variable - especially in complex terrain. This also becomes obvious when comparing the snowmelt rates on 23 April 2014 in Fig. 10a. Differences of observed and simulated snowmelt rates might result from the non-representativeness of point measurements for catchment averages and refer to the scale issue of data collection. The peak melt period was characterized by less spatial and day-to-day variation in observed melt rates (Fig. 10). The modeled daily snowmelt during this period was similar for north- and south-facing slopes, likely because of higher melt rates but also a smaller snow-covered area of the south-facing slope in contrast to the north-facing slope during peak melt (Fig. 11). The model performance was good for SWE (Table 3) and snow-cover extent (Figs. 2 and 9). The spatial variation of snowpack isotopic composition are significant, as can be seen in the differences for north- and south-facing slopes, and also shown by Carey and Quinton (2004), Dahlke and Lyon (2013), and Dietermann and Weiler (2013) in their studied high-gradient catchments, whereas there are unclear differences for the spatial variation of snowmelt isotopic signals in the literature. It is not clear to which extent altitude is important, as Dietermann and Weiler (2013) stated that a potential elevation effect (decrease in snowmelt $\delta^{18} \mathrm{O}$ with elevation) is likely to be disturbed by melting processes (isotopic enrichment) depending on catchment morphology (aspect, slope) during the ablation period. Beaulieu et al. (2012) detected elevation as a predictor, which explained most of the variance they observed in snowmelt $\delta^{18} \mathrm{O}$ from four distributed snow lysimeters. Moore (1989) and Laudon et al. (2007) found no significant difference of $\delta^{18} \mathrm{O}$ in their lysimeter outflows, which was likely due to the small elevation gradient of their catchments that favor an isotopically homogenous snowpack, whereas Unnikrishna et al. (2002) found remarkable small-scale spatial variability. An altitudinal gradient was not considered in this study, but possible effects on IHS are discussed in Sect. 5.6. The difference of snowmelt (not snowpack) isotopic signature between north- and south-facing slopes was clearly shown in this study. The dataset is small, but reveals clear differences induced by varying magnitudes and timing of melt due to differences in solar radiation on the opposing slopes (Fig. 7). Temporal variability in snowmelt isotopic composition is greater for the north-facing slope compared to the south-facing slope (Fig. 7), which was also pointed out by Carey and Quinton (2004) in their subarctic catchment. Earlier homogenization in the isotopic profile of the snowpack and earlier melt out are responsible for this phenomenon (cf.
Dinçer et al., 1970; Unnikrishna et al., 2002). Fractionation processes likely controlled this homogenization of the snowpack between the two investigated melt events. The isotopic homogenization of the snowpack on the south-facing slope started earlier in the melting period and caused a smaller spatial and temporal variation compared to the north-facing snowpack, as was also reported by Unnikrishna et al. (2002) and Dinçer et al. (1970). The differences between these investigated snowpacks were larger in the early melt season than in the peak melt season. This affects the IHS results, especially because the snowmelt contributions from the southand north-facing slope - with marked isotopic differences - were distinct. Due to melt, fractionation processes proceeded and the snowpack likely became more homogenous throughout the snowmelt season. However, inter-daily variations of snowpack isotopic composition, especially for the north-facing slope, were still observable during the peak melt period. The gradual isotopic enrichment of the snowpack was also observed for snowmelt, as described by many others (Feng et al., 2002; Shanley et al., 2002; Taylor et al., 2001, 2002; Unnikrishna et al., 2002).

Intra-daily variations of snowmelt $\delta^{18} \mathrm{O}$ could be quantified for two sites (Fig. 8). At S1 on the south-facing slope during the early melt event, the $0.1 \%$ range in $\delta^{18} \mathrm{O}(n=5)$ was smaller than the range at $\mathrm{N} 2$ on the north-facing slope during the peak melt event $(n=3$, range $=0.2 \%)$. This subdaily variability is markedly smaller than the differences between the investigated slopes (cf. Table 1), which ranged from $0.8 \%$ o (peak melt) to $1.4 \%$ (early melt). Unnikrishna et al. (2002) described significant temporal variations of snowmelt $\delta^{18} \mathrm{O}$ during large snowmelt events (peak melt). However, these findings could not be confirmed within in this study, probably due to the temporally limited data and should be tested with a larger dataset. The bulk sample at S1 (23 April 2014) was isotopically closer to the sub-daily values compared to the bulk sample at N2 (7 June 2014) that was at the upper range of the sub-daily samples (Fig. 8). Therefore, one could argue that for the south-facing slope there is a negligible uncertainty if one uses a single snowmelt value (at one time) for IHS instead of using a bulk sample, but this is not the case for the north-facing slope (Fig. 8, site N2). Unfortunately the sample numbers are small, because more frequent and more distributed sampling (at different sites) was not feasible due to logistical issues. Hence, these results should be used with caution and should be investigated in further studies. If the focus and the scale of the study is not on the sub-daily variability, the authors recommend the use of bulk samples, because these integrate (automatically weighed with snowmelt rate) the diurnal variations.

\subsection{Validity of isotopic hydrograph separation}

The validity of IHS relies on several assumptions (cf. Sect. 3.3; Buttle, 1994; Klaus and McDonnell, 2013). 
The assumption that the isotopic composition of event and pre-event water differ significantly (assumption 1) was successfully proven, because the snowmelt isotopic values were markedly lower than pre-event baseflow values (cf. Tables 2 and 4, Fig. 5). Spatiotemporal variations of event water isotopic composition (assumption 2) were accounted for by collecting daily and sub-daily samples during both events throughout the freshet period and meltwater sampling at a north- and south-facing slope, respectively. The spatially variable input of event water was considered by dividing the catchment into two parts - a north- and a southfacing slope. This study supports the findings of Dahlke and Lyon (2013) and Carey and Quinton (2004), emphasizing the highly variable snowpack/snowmelt isotopic composition in complex topography catchments due to enrichment. The temporal variability of event water isotopic composition was considered by using bulk daily samples, which integrate snowmelt from the entire diurnal melting cycle, but smooth out a sub-daily signal. Because the focus of this study was more on the inter-event than the intra-daily scale, this approach seemed reasonably reliable. The spatiotemporal variability of the isotopic composition of pre-event water (assumption 3) is a major limitation and could not be clearly identified due to a lack of data and was therefore assumed to be constant. Small differences between the pre-event samples $\left(-15.00\right.$ and $-15.05 \%$ o for $\left.\delta^{18} \mathrm{O}\right)$ and post-event stream water isotopic composition support this assumption (Table 2). The assumption of soil water having the same isotopic composition as groundwater in time and space (assumption 4) is critical. Some studies reveal no significant differences (e.g., Laudon et al., 2007), whereas others do (e.g., Sklash and Farvolden, 1979). Isotopic differences between groundwater and soil water were not considered due to a lack of data. Furthermore, it is not known to which degree the vadose zone contributes to baseflow in the study area. Winter baseflow used in the analyses is assumed to integrate mainly groundwater and partly soil water. Soil water could be hypothesized to have a negligible contribution to baseflow during winter due to the recession of the soil water flow in autumn and frozen soils in winter. The assumption that no or minimal surface storage occurs (assumption 5) is plausible because water bodies like lakes or wetlands do not exist in the study catchment and due to the steep topography detention storage is likely limited. The transit time of snowmelt was assumed to be less than $24 \mathrm{~h}$. This short travel time is characteristic for headwater catchments (Lundquist et al., 2005) with high in-channel flow velocities, steep hillslopes, a high drainage density with snow-fed tributaries, thin soils, most snowmelt originating from the edge of the snow line (small average travel distances), partly frozen soil, and observed surface overland flow. The state-of-the-art method (runCE) to include residence times of snowmelt in the event water reservoir proposed by Laudon et al. (2002) was applied in several IHS studies (Beaulieu et al., 2012; Carey and Quin- ton, 2004; Petrone et al., 2007), but was not feasible due to the short-term character and temporally limited data.

\subsection{Hydrograph separation results and inferred runoff generation processes}

Large contributions from snowmelt to streamflow are common in high-elevation catchments. Daily contributions between 35 and $75 \%$ in the Rofen valley are comparable to the results of studies conducted in other mountainous regions, mostly outside the European Alps. Beaulieu et al. (2012) estimated snowmelt contributions ranging from 7 to $66 \%$ at the seasonal scale for their $2.4 \mathrm{~km}^{2}$ catchment and reported contributions of 34 and $62 \%$, for the early melt and peak melt, respectively. The hydrograph was dominated by pre-event water during early melt in April (Fig. 4c), which is in accordance with the results obtained by other IHS studies (Beaulieu et al., 2012; Laudon et al., 2004, 2007; Moore, 1989). The snowmelt contribution increased as the freshet period progressed and peaked with high contributions at the beginning of June. Beaulieu et al. (2012) and Sueker et al. (2000) reported comparable results for their physically similar catchments during peak melt with 62 and up to $76 \%$ event water contributions to streamflow, respectively. At the event-scale comparable studies are rare. Engel et al. (2016) report a maximum daily snowmelt contribution estimated with a three-component hydrograph separation of $33 \%$ for an $11 \mathrm{~km}^{2}$ southwest of the Rofen valley with similar physiographic characteristics, but on the southern side of the main Alpine ridge. It should be mentioned that in their study, runoff was fed by three components (snowmelt, glacier melt, and groundwater) and lower snowmelt contributions were prevalent because most of the catchment area (69\%) was snow free.

Initial snowmelt events flush the pre-event water reservoir as snowmelt infiltrates into the soil and causes the pre-event water to exfiltrate and contribute to the streamflow. As the soil and groundwater reservoir becomes gradually filled with new water (snowmelt), the event water fraction in the stream increases. The system is also wetter during peak melt. The dominance of event water in the hydrograph is interpreted as an outflow of pre-event water stored in the subsurface and the gradual replenishment of the soil and groundwater reservoirs by event water. The higher water table - compared to the early melt period - could cause a transmissivity feedback mechanism (Bishop, 1991). This is a common mechanism in catchments with glacial till (Bishop et al., 2011) characterized by higher transmissivities and hence increased lateral flow velocities towards to the surface. Runoff generation is spatially very variable in the study area. There are areas (meadow patches between rock fields) where saturation excess overland flow is dominant (observed mainly at plots S1, S2, and Wind) and areas (with larger rocks and debris) where rapid shallow subsurface flow can be assumed (plot N2). Catchment morphology controls various 
hydrologic processes and hence the shape of the hydrograph. Upslope residence times of snowmelt are usually smaller due to thin soils (observed during the field work), steeper slopes (Sueker et al., 2000), and higher contributing areas of glaciers with impermeable ice (Behrens et al., 1978), and would be indicators for the more flashy hydrograph during the peak melt season.

\subsection{Impact of spatial varying snowmelt and its isotopic composition on isotope-based hydrograph separation and assessment of weighting approaches}

Klaus and McDonnell (2013) stress in their review paper the need to investigate the effects of the spatially varying snowmelt and its isotopic composition on IHS. This study quantified the impact of the spatially varying isotopic composition of snowmelt between north- and south-facing slopes on IHS results for the first time. The IHS results were more sensitive to the spatial variability of snowmelt $\delta^{18} \mathrm{O}$ than to spatial variations of snowmelt rates (Table 6). This is even more pronounced for the peak melt period, because snowmelt rates were similar for the north- and south-facing slope, probably due to a ripe snow cover throughout the catchment. The difference in volumetric snowmelt contribution to streamflow at the event-scale determined using the five different weighting methods for IHS is maximum $24 \%$ (NORTH approach vs. SOUTH approach). The data show that the variations between the weighting approaches (VWS, VWO, and VWE) are higher throughout the early melt season (Table 6), because small-scale variability of snowmelt and its isotopic composition are more pronounced in the early melt season. Thus, the influence of spatial variability of snowmelt and its isotopic composition on the event water fraction calculated with IHS is larger during this time. Melt rates strongly differ between the south- and the northfacing slope (Fig. 11), which were deceptively gathered by manually measured SWE, likely due to micro-topographic effects. As the contributions from both slopes are used in Eq. (3), they strongly influence the average isotopic composition of event water. The weighting method SOUTH (or NORTH) represents the hypothetical and most extreme scenario in which only one sampling site is used for the IHS analysis. Because snowmelt is more enriched in $\delta^{18} \mathrm{O}$ and closer to pre-event water isotopic composition on the southfacing slope during peak melt, this scenario has the greatest effect on IHS and leads to the strongest deviation in estimated snowmelt fractions (up to $15 \%$ overestimation compared to the VWS approach). These scenarios (NORTH/SOUTH) are theoretical and it is obvious that it is not recommended to conduct a IHS analysis by using only samples from either north- or south-facing slopes in catchments with complex terrain. Similar to the VWE method, snowmelt isotopic data were not volume weighted in other studies (e.g., Engel et al., 2016) where snowmelt data were not available. This has a more distinct effect on IHS during the early melt season be- cause of the higher spatiotemporal variability in snowmelt (and its isotopic composition) compared to the peak melt season and led to a deviation in the snowmelt fraction in streamflow of 2 and $3 \%$ compared to the VWS and VWO approaches, respectively. These differences are small, because the differing snowmelt and isotopic values offset each other in this particular case (Table 6). Nevertheless, the results of VWS are more correct for the right reason, because single observed plot-scale melt rates do not represent distributed snowmelt contribution at the catchment scale. Therefore, one can hypothesize that distributed simulated melt rates enhance the reliability of IHS, whereas plot-scale weighting introduces a large error caused by the difficulty in finding locations that represent the average melt rate in complex terrain.

\subsection{Limitations of the study}

Collecting water samples in high-elevation terrain is challenging due to limited access and high risk (e.g., avalanches), limiting high-frequency sampling. Hence, some limitations are inherent in this study. Potential elevation effects on snowmelt isotopic composition were not tested. The opposing sampling sites (S1-N1 and S2-N2) were at the same elevation (Fig. 1). It was assumed that the differences in northand south-facing slopes were much greater than a possible altitudinal gradient in snowmelt isotopic composition. This hypothesis was not tested, but based on the results of other studies (Dietermann and Weiler, 2013). However, accounting for a potential altitudinal gradient (decrease in snowmelt $\delta^{18} \mathrm{O}$ with elevation) would lead to more depleted isotopic signatures of event water and hence to lower event water fractions.

Another disadvantage is that no snow survey was conducted prior to the onset of snowmelt (peak accumulation) to estimate spatial variability in bulk snow $\delta^{18} \mathrm{O}$. Because snowmelt is used for applying IHS, it is not clear to which degree the spatial variability of the snowpack isotopic composition is important. Two-component isotope-based hydrograph separation was successfully applied using the snowmelt and baseflow endmembers, but potential contributions of glacier melt were neglected (here defined as ice/firn melt). Because glaciers in the catchment were still covered by snow during the peak melt season, a significant contribution from ice/firn melt was assumed to be unlikely. Nevertheless, negligible amounts of basal (ice) meltwater could originate from temperate glaciers. No samples could be collected during the recession of the hydrograph (at night). Even though the spatial variability of the event water signal was the focus of the study, only temporal variability was considered in the Genereux-based uncertainty analyses. Although the temporal variability of winter baseflow isotopic composition seems to be insignificant, the sample number $(n=2)$ could be too small to characterize the pre-event component and should be clearly investigated in future work. Penna et al. (2016) used two approaches to determine the isotopic composition 
of pre-event water and described differences in the estimated event water contributions during snowmelt events. They advise to take pre-event samples prior to the onset of the melt season because pre-event samples taken prior to the onset of the diurnal melt cycle could be affected by snowmelt water from the previous melt pulses and therefore could lead to underestimated snowmelt fractions and high uncertainties. Furthermore, model results and observed discharges were assumed to be free of error in the analyses. As pointed out, instrumentation and accessibility are major problems for highelevation studies. For this study it turned out that composite snowmelt samples were easier to collect, representing the day-integrated melt signal. A denser network of melt collectors would be desirable, as well as a snow lysimeter to gain high-frequency data automatically. Representative samples of the elevation zones and different vegetation belts could be important too, especially in partly forested catchments with a distinct relief (cf. Unnikrishna et al., 2002).

\section{Conclusions}

This study provides new insights into the variability of the isotopic composition in snowmelt and highlights its impact on IHS results in a high-elevation environment. The spatial variability in snowmelt isotopic signature was considered by experimental investigations on south- and north-facing slopes to define the isotopic composition of the snowmelt endmember with greater accuracy. This study clearly shows that distributed snowmelt rates obtained from a model based on meteorological data from local automatic weather stations affect the weighting of the event water isotopic signal, and hence the estimation of the snowmelt fraction in the stream by IHS. The study provides a variety of relevant findings that are important for hydrologic research in highalpine environments. There was a distinct spatial variability in snowmelt between north- and south-facing slopes, especially during the early melt season. The isotopic composition of snowmelt water was significantly different between north-facing and south-facing slopes, which resulted in a pronounced effect on the estimated snowmelt contributions to streamflow with IHS. The IHS results were more sensitive to the spatial variability of snowmelt $\delta^{18} \mathrm{O}$ than to spatial variation of snowmelt rates. The differences in the estimated snowmelt fraction due to the weighting methods used for IHS were as large as $24 \%$. This study also shows that it is hardly possible to characterize the event water signature of larger slopes based on plot-scale snowmelt measurements. Applying a distributed model reduced the uncertainty of the spatial snowmelt variability inherent to point-scale observations. Hence, applying the VWS method provided more reasonable results than the VWO method. This study highlighted that the selection of sampling sites has a major effect on IHS results. Sampling at least north-facing and south-facing slopes in complex terrain and using distributed melt rates to weight the snowmelt isotopic composition of the differing exposures is therefore highly recommended for applying snowmelt-based IHS.

\section{Data availability}

Isotope and field data (i.e. snow observations) can be obtained from the corresponding author upon request.

Acknowledgements. The authors wish to thank the Institute of Atmospheric and Cryospheric Sciences of the University of Innsbruck, the Zentralanstalt für Meteorologie and Geodynamik, the Hydrographic Service of Tyrol and the TIWAG-Tiroler Wasserkraft AG for providing hydrological and meteorological data, the Amt der Tiroler Landesregierung for providing the digital elevation model, the Center of Stable Isotopes (CSI) for laboratory support, as well as many other individuals, who have helped to collect data in the field. We also thank the reviewers for their valuable suggestions that have much improved the manuscript, and the editor for the careful handling of the manuscript.

Edited by: I. van Meerveld

Reviewed by: S. Pohl and one anonymous referee

\section{References}

Ahluwalia, R. S., Rai, S. P., Jain, S. K., Kumar, B., and Dobhal, D. P.: Assessment of snowmelt runoff modelling and isotope analysis: a case study from the western Himalaya, India, Ann. Glaciol., 54, 299-304, doi:10.3189/2013AoG62A133, 2013.

APCC: Austrian Assessment Report (AAR14). Summary for Policymakers (SPM), Austrian Panel on Climate Change, Vienna, Austria, 2014.

Árnason, B., Buason, T., Martinec, J., and Theodorson, P.: Movement of water through snowpack traced by deuterium and tritium, in: The role of snow and ice in hydrology, Proc. Banff Symp., edited by: UNESCO-WMO-IAHS, IAHS Publ. No. 107, 1973.

Beaulieu, M., Schreier, H., and Jost, G.: A shifting hydrological regime: a field investigation of snowmelt runoff processes and their connection to summer base flow, Sunshine Coast, British Columbia, Hydrol. Process., 26, 2672-2682, doi:10.1002/hyp.9404, 2012.

Behrens, H., Moser, H., Oerter, H., Rauert, W., Stichler, W., and Ambach, W.: Models for the runoff from a glaciated catchment area using measurements of environmental isotope contents, Isotope Hydrology Vol. 11, W-05, Proceedings of a Symposium, Neuherberg, 19-23 June 1978, IAEA, Vienna, IAEASM-228/41, 2, 829-846, 1978.

Birkel, C. and Soulsby, C.: Advancing tracer-aided rainfall-runoff modelling: a review of progress, problems and unrealised potential, Hydrol. Process., 29, 5227-5240, doi:10.1002/hyp.10594, 2015.

Birkel, C., Tetzlaff, D., Dunn, S. M., and Soulsby, C.: Using time domain and geographic source tracers to conceptualize streamflow generation processes in lumped rainfall-runoff models, 
Water Resour. Res., 47, W02515, doi:10.1029/2010WR009547, 2011.

Bishop, K.: Episodic increase in stream acidity, catchment flow pathways and hydrograph separation, $\mathrm{PhD}$ thesis, University of Cambridge, 246 pp., 1991.

Bishop, K., Seibert, J., Nyberg, L., and Rodhe, A.: Water storage in a till catchment. II: Implications of transmissivity feedback for flow paths and turnover times, Hydrol. Process., 25, 3950-3959, doi:10.1002/hyp.8355, 2011.

Braithwaite, R. J. and Olesen, O. B.: Calculation of glacier ablation from air temperature, West Greenland, in: Glacier Fluctuations and Climatic Change, Glaciology and Quaternary Geology, edited by: Oerlemans, J., Kluwer Academic Publisher, Dordrecht, 1989.

Buttle, J. M.: Isotope hydrograph separations and rapid delivery of pre-event water from drainage basins, Prog. Phys. Geog., 18, 1641, doi:10.1177/030913339401800102, 1994.

Capell, R., Tetzlaff, D., and Soulsby, C.: Can time domain and source area tracers reduce uncertainty in rainfall-runoff models in larger heterogeneous catchments?, Water Resour. Res., 48, W09544, doi:10.1029/2011WR011543, 2012.

Carey, S. K. and Quinton, W. L.: Evaluating snowmelt rnoff generation in a discontinuous permafrost catchment using stable isotope, hydrochemical and hydrometric data, Nord. Hydrol., 35, 309-324, 2004.

Clark, I. D. and Fritz, P.: Environmental Isotopes in Hydrogeology, Lewis Publishers, Ney York, 342 pp., 1997.

CLC: Corine Land Cover 2006 raster data, European Environment Agency. The European Topic Centre on Land Use and Spatial Information, available at: http://www.eea.europa. eu/data-and-maps/data/clc-2006-raster (last access: 10 December 2015), 2006.

Cooper, L. W.: Isotopic fractionation in snow cover, in: Isotope tracers in catchment hydrology, edited by: Kendall, C. and McDonnell, J. J., Elsevier Science, Amsterdam, Netherlands, 119-136, 2006.

Corripio, J. G.: Vectorial algebra algorithms for calculating terrain parameters from DEMs and the position of the sun for solar radiation modelling in mountainous terrain, Int. J. Geogr. Inf. Sci., 17, 1-23, 2003.

Dahlke, H. E. and Lyon, S. W.: Early melt season snowpack isotopic evolution in the Tarfala valley, northern Sweden, Ann. Glaciol., 54, 149-156, doi:10.3189/2013AoG62A232, 2013.

Dietermann, N. and Weiler, M.: Spatial distribution of stable water isotopes in alpine snow cover, Hydrol. Earth Syst. Sci., 17, 26572668, doi:10.5194/hess-17-2657-2013, 2013.

Dinçer, T., Payne, B. R., Florkowski, T., Martinec, J., and Tongiorgi, E.: Snowmelt runoff from measurements of tritium and oxygen-18, Water Resour. Res., 6, 110-124, doi:10.1029/WR006i001p00110, 1970.

Engel, M., Penna, D., Bertoldi, G., Dell'Agnese, A., Soulsby, C., and Comiti, F.: Identifying run-off contributions during meltinduced run-off events in a glacierized alpine catchment, Hydrol. Process., 30, 343-364, doi:10.1002/hyp.10577, 2016.

Feng, X., Taylor, S., Renshaw, C. E., and Kirchner, J. W.: Isotopic evolution of snowmelt 1 . A physically based onedimensional model, Water Resour. Res., 38, 35-31-35-38, doi:10.1029/2001WR000814, 2002.
Genereux, D.: Quantifying uncertainty in tracer-based hydrograph separations, Water Resour. Res., 34, 915-919, doi:10.1029/98WR00010, 1998.

Greuell, W., Knap, W. H., and Smeets, P. C.: Elevational changes in meteorological variables along a midlatitude glacier during summer, J. Geophys. Res.-Atmos., 102, 25941-25954, doi:10.1029/97JD02083, 1997.

Gruber, S.: A mass-conserving fast algorithm to parameterize gravitational transport and deposition using digital elevation models, Water Resour. Res., 43, W06412, doi:10.1029/2006WR004868, 2007.

Haeberli, W.: Untersuchungen zur Verbreitung von Permafrost zwischen Flüelapass und Piz Grialetsch (Graubünden), Mitteilungen der Versuchsanstalt für Wasserbau, Hydrologie und Glaziologie der ETH Zürich, 1975.

Hanzer, F., Marke, T., and Strasser, U.: Distributed, explicit modeling of technical snow production for a ski area in the Schladming region (Austrian Alps), Cold Reg. Sci. Technol., 108, 113-124, doi:10.1016/j.coldregions.2014.08.003, 2014.

Hanzer, F., Helfricht, K., Marke, T., and Strasser, U.: Multilevel spatiotemporal validation of snow/ice mass balance and runoff modeling in glacierized catchments, The Cryosphere, 10, 1859-1881, doi:10.5194/tc-10-1859-2016, 2016.

Helfricht, K.: Analysis of the spatial and temporal variation of seasonal snow accumulation in Alpine catchments using airborne laser scanning. Basic research for the adaptation of spatially distributed hydrological models to mountain regions, $\mathrm{PhD}$, University of Innsbruck, Innsbruck, 134 pp., 2014.

Hock, R.: Temperature index melt modelling in mountain areas, J. Hydrol., 282, 104-115, doi:10.1016/S0022-1694(03)00257-9, 2003.

Hooper, R. P. and Shoemaker, C. A.: A Comparison of Chemical and Isotopic Hydrograph Separation, Water Resour. Res., 22, 1444-1454, doi:10.1029/WR022i010p01444, 1986.

Huth, A. K., Leydecker, A., Sickman, J. O., and Bales, R. C.: A two-component hydrograph separation for three high-elevation catchments in the Sierra Nevada, California, Hydrol. Process., 18, 1721-1733, doi:10.1002/hyp.1414, 2004.

IPCC: Summary for Policymakers. Climate Change 2013: The Physical Science Basis. Contribution of Working Group I to the Fifth Assessment Report of the Intergovernmental Panel on Climate Change, Cambridge, United Kindom and New York, NY, USA, 2013.

Klaus, J. and McDonnell, J. J.: Hydrograph separation using stable isotopes: Review and evaluation, J. Hydrol., 505, 47-64, doi:10.1016/j.jhydrol.2013.09.006, 2013.

Laudon, H., Hemond, H. F., Krouse, R., and Bishop, K. H.: Oxygen 18 fractionation during snowmelt: Implications for spring flood hydrograph separation, Water Resour. Res., 38, 40-41-4010, doi:10.1029/2002WR001510, 2002.

Laudon, H., Seibert, J., Köhler, S., and Bishop, K.: Hydrological flow paths during snowmelt: Congruence between hydrometric measurements and oxygen 18 in meltwater, soil water, and runoff, Water Resour. Res., 40, W03102, doi:10.1029/2003WR002455, 2004.

Laudon, H., Sjöblom, V., Buffam, I., Seibert, J., and Mörth, M.: The role of catchment scale and landscape characteristics for runoff generation of boreal streams, J. Hydrol., 344, 198-209, doi:10.1016/j.jhydrol.2007.07.010, 2007. 
Lee, J., Feng, X., Faiia, A. M., Posmentier, E. S., Kirchner, J. W., Osterhuber, R., and Taylor, S.: Isotopic evolution of a seasonal snowcover and its melt by isotopic exchange between liquid water and ice, Chem. Geol., 270, 126-134, doi:10.1016/j.chemgeo.2009.11.011, 2010.

Liston, G. E. and Elder, K.: A Distributed Snow-Evolution Modeling System (SnowModel), J. Hydrometeorol., 7, 1259-1276, doi:10.1175/JHM548.1, 2006.

Liu, F., Williams, M. W., and Caine, N.: Source waters and flow paths in an alpine catchment, Colorado Front Range, United States, Water Resour. Res., 40, 1-16, doi:10.1029/2004WR003076, 2004.

Lundquist, J. D. and Cayan, D. R.: Seasonal and Spatial Patterns in Diurnal Cycles in Streamflow in the Western United States, J. Hydrometeorol., 3, 591-603, doi:10.1175/15257541(2002)003<0591:SASPID>2.0.CO;2, 2002.

Lundquist, J. D., Dettinger, M. D., and Cayan, D. R.: Snowfed streamflow timing at different basin scales: Case study of the Tuolumne River above Hetch Hetchy, Yosemite, California, Water Resour. Res., 41, W07005, doi:10.1029/2004WR003933, 2005.

Marke, T.: Development and Application of a Model Interface to couple Regional Climate Models with Land Surface Models for Climate Change Risk Assessment in the Upper Danube Watershed, Dissertation der Fakultät für Geowissenschaften, Digitale Hochschulschriften der LMU München, München, 2008.

Marke, T., Strasser, U., Hanzer, F., Stötter, J., Wilcke, R. A. I., and Gobiet, A.: Scenarios of Future Snow Conditions in Styria (Austrian Alps), J. Hydrometeorol., 16, 261-277, doi:10.1175/JHMD-14-0035.1, 2015.

Martinec, J., Siegenthaler, U., Oeschger, H., and Tongiorgi, E.: New insights into the run-off mechanism by environmental isotopes, in: Isotope techniques in groundwater hydrology, Proceedings of an International Symposium, IAEA, Vienna, Austria, 1974.

Mast, A. M., Kendall, K., Campbell, D. H., Clow, D. W., and Back, J.: Determination of hydrologic pathways in an alpinesubalpine basin using isotopic and chemical tracers, Loch Vale Watershed, Colorado, USA, in: Biogeochemistry of Seasonally Snow-Covered Catchments, edited by: Tonnessen, K., William, M., and Tranter, M., Int. Assoc. of Hydrol. Sci. Proc., Boulder, Colorado, 1995.

Maulé, C. P. and Stein, J.: Hydrologic Flow Path Definition and Partitioning of Spring Meltwater, Water Resour. Res., 26, 29592970, doi:10.1029/WR026i012p02959, 1990.

Moore, R. D.: Tracing runoff sources with deuterium and oxygen88 during spring melt in a headwater catchment, southern Laurentians, Quebec, J. Hydrol., 112, 135-148, doi:10.1016/00221694(89)90185-6, 1989.

Pellicciotti, F., Brock, B., Strasser, U., Burlando, P., Funk, M., and Corripio, J.: An enhanced temperature-index glacier melt model including the shortwave radiation balance: development and testing for Haut Glacier d'Arolla, Switzerland, J. Glaciol., 51, 573587, 2005.

Penna, D., Engel, M., Mao, L., Dell'Agnese, A., Bertoldi, G., and Comiti, F.: Tracer-based analysis of spatial and temporal variations of water sources in a glacierized catchment, Hydrol. Earth Syst. Sci., 18, 5271-5288, doi:10.5194/hess-18-52712014, 2014.
Penna, D., van Meerveld, H. J., Zuecco, G., Dalla Fontana, G., and Borga, M.: Hydrological response of an Alpine catchment to rainfall and snowmelt events, J. Hydrol., 537, 382-397, doi:10.1016/j.jhydrol.2016.03.040, 2016.

Petrone, K., Buffam, I., and Laudon, H.: Hydrologic and biotic control of nitrogen export during snowmelt: A combined conservative and reactive tracer approach, Water Resour. Res., 43, 1-13, doi:10.1029/2006WR005286, 2007.

Pinder, G. F. and Jones, J. F.: Determination of the groundwater component of peak discharge from the chemistry of total runoff, Water Resour. Res., 5, 438-445, doi:10.1029/WR005i002p00438, 1969.

Pomeroy, J. W., Toth, B., Granger, R. J., Hedstrom, N. R., and Essery, R. L. H.: Variation in Surface Energetics during Snowmelt in a Subarctic Mountain Catchment, J. Hydrometeorol., 4, 702-719, doi:10.1175/15257541(2003)004<0702:VISEDS>2.0.CO;2, 2003.

Rohrer, M. B.: Die Schneedecke im Schweizer Alpenraum und ihre Modellierung, PhD thesis, Swiss Federal Institute of Technology in Zurich, Switzerland, 178 pp., 1992.

Schuler, T.: Investigation of water drainage through an alpine glacier by tracer experiments and numerical modeling, $\mathrm{PhD}$ thesis, Swiss Federal Institute of Technology in Zurich, Switzerland, 140 pp., 2002.

Shanley, J. B., Kendall, C., Smith, T. E., Wolock, D. M., and McDonnell, J. J.: Controls on old and new water contributions to stream flow at some nested catchments in Vermont, USA, Hydrol. Process., 16, 589-609, doi:10.1002/hyp.312, 2002.

Sklash, M. G. and Farvolden, R. N.: The role of groundwater in storm runoff, J. Hydrol., 43, 45-65, doi:10.1016/00221694(79)90164-1, 1979.

Sklash, M. G., Farvolden, R. N., and Fritz, P.: A conceptual model of watershed response to rainfall, developed through the use of oxygen-18 as a natural tracer, Can. J. Earth Sci., 13, 271-283, doi:10.1139/e76-029, 1976.

Stichler, W.: Snowcover and Snowmelt Processes Studied by Means of Environmental Isotopes, in: Seasonal Snowcovers: Physics, Chemistry, Hydrology, edited by: Jones, H. G. and OrvilleThomas, W. J., D. Reidel Publishing Company, Dordrecht, Holland, 673-726, 1987.

Strasser, U.: Modelling of the mountain snow cover in the Berchtesgaden National Park, Research Rep. 55, Berchtesgaden, 2008.

Strasser, U., Corripio, J., Pellicciotti, F., Burlando, P., Brock, B., and Funk, M.: Spatial and temporal variability of meteorological variables at Haut Glacier d'Arolla (Switzerland) during the ablation season 2001: Measurements and simulations, J. Geophys. Res.-Atmos., 109, D03103, doi:10.1029/2003JD003973, 2004.

Strasser, U., Bernhardt, M., Weber, M., Liston, G. E., and Mauser, W.: Is snow sublimation important in the alpine water balance?, The Cryosphere, 2, 53-66, doi:10.5194/tc-2-53-2008, 2008.

Strasser, U., Warscher, M., and Liston, G. E.: Modeling SnowCanopy Processes on an Idealized Mountain, J. Hydrometeorol., 12, 663-677, doi:10.1175/2011JHM1344.1, 2011.

Sueker, J. K., Ryan, J. N., Kendall, C., and Jarrett, R. D.: Determination of hydrologic pathways during snowmelt for alpine/subalpine basins, Rocky Mountain National Park, Colorado, Water Resour. Res., 36, 63-75, doi:10.1029/1999WR900296, 2000. 
Taylor, S., Feng, X., Kirchner, J. W., Osterhuber, R., Klaue, B., and Renshaw, C. E.: Isotopic evolution of a seasonal snowpack and its melt, Water Resour. Res., 37, 759-769, doi:10.1029/2000WR900341, 2001.

Taylor, S., Feng, X., Williams, M., and McNamara, J.: How isotopic fractionation of snowmelt affects hydrograph separation, Hydrol. Process., 16, 3683-3690, doi:10.1002/hyp.1232, 2002.

Uhlenbrook, S. and Leibundgut, C.: Process-oriented catchment modelling and multiple-response validation, Hydrol. Process., 16, 423-440, doi:10.1002/hyp.330, 2002.

Unnikrishna, P. V., McDonnell, J. J., and Kendall, C.: Isotope variations ni a Sierra Nevada snowpack and their relation to meltwater, J. Hydrol., 260, 38-57, 2002.

Warscher, M., Strasser, U., Kraller, G., Marke, T., Franz, H., and Kunstmann, H.: Performance of complex snow cover descriptions in a distributed hydrological model system: A case study for the high Alpine terrain of the Berchtesgaden Alps, Water Resour. Res., 49, 2619-2637, doi:10.1002/wrcr.20219, 2013.
Weingartner, R. and Aschwanden, H.: Discharge regime - the basis for the estimation of average flows, in: Hydrological Atlas of Switzerland, Plate 5.2, Bern, 1992.

Williams, M. W., Seibold, C., and Chowanski, K.: Storage and release of solutes from a subalpine seasonal snowpack: soil and stream water response, Niwot Ridge, Colorado, Biogeochemistry, 95, 77-94, doi:10.1007/s10533-009-9288-x, 2009.

Zappa, M.: Objective quantitative spatial verification of distributed snow cover simulations - an experiment for the whole of Switzerland, Hydrolog. Sci. J., 53, 179-191, doi:10.1623/hysj.53.1.179, 2008.

Zhou, S., Nakawo, M., Hashimoto, S., and Sakai, A.: The effect of refreezing on the isotopic composition of melting snowpack, Hydrol. Process., 22, 873-882, doi:10.1002/hyp.6662, 2008. 